\title{
Analiza polskiego i austriackiego przekazu medialnego wokół 72. rocznicy wyzwolenia byłego niemieckiego obozu koncentracyjnego KL Gusen
}

\section{Uwagi wstępne}

Przyjmuje się, że w okresie istnienia KL Gusen, tj. od 25 maja 1940 roku do 5 maja 1945 roku, kiedy to został wyzwolony przez armię amerykańska, do obozu zesłano ok. 71 tys. osób 27 narodowości. Trafiali tam przede wszystkim Polacy przebywający wcześniej w innych obozach koncentracyjnych, głównie przedstawiciele elit. Z tego powodu obóz ten jest nazywany „małym Katyniem”. Według różnych szacunków, w KL Gusen zginęło od 27 do 35 tys. polskich obywateli.

Dla celów niniejszego artykułu poddałam analizie polskie i austriackie materiały prasowe, internetowe, telewizyjne i radiowe poświęcone Gusen, które ukazały się między 1 kwietnia a 30 czerwca 2017 roku$^{1}$. Ze względu na termin obchodów 72. rocznicy

1 Kwerenda objęła wiodące, ogólnokrajowe tytuły prasowe, portale internetowe oraz audycje telewizyjne i radiowe z Polski („Dziennik Gazeta Prawna”, „Fakt”, „Gazeta Polska Codziennie”, „Gazeta Wyborcza”, „Nasz Dziennik”, „Polska The Times”, „Rzeczpospolita”, „Super Express”; „Do Rzeczy”, „Gazeta Polska”, „Newsweek Polska”, „Polityka”, „Przegląd”, „Tygodnik Powszechny”, „Wprost”, „W Sieci”; Polskie Radio Program I, II i III, Radio Maryja, Radio Zet, RMF FM, Tok FM; TVN, TVN24, TVN BiŚ, TVP1, TVP2, TVP Info, Polsat, Polsat News, Superstacja) i Austrii („Der Standard”, „Die Presse”, „Heute”, „Kleine Zeitung”, „Kronen Zeitung”, „Kurier”, „Österreich”, „Salzburger Nachrichten”; „Wiener Zeitung”, „Profil”, Österreich 1, Radio Maria Österreich; ATV, ORF eins, ORF III, Puls 4). Uwzględnione zostały także lokalne media kraju związkowego Górna Austria: „BezirksRundschau”, „Neues Volksblatt”, „Oberösterreichische Nachrichten”, „Oberösterreichische Rundschau”, „Tips”; Radio Arabella Oberösterreich; ORF2. 
wyzwolenia obozu koncentracyjnego Gusen (5-8 maja 2017 roku) najwięcej materiałów przypada na pierwszą połowę maja 2017 roku.

Materiały do analizy pozyskałam na podstawie ręcznego przeglądu prasy $\mathrm{i}$ internetu, który uzupełniłam o wycinki prasowe od firm zajmujących się monitorowaniem mediów w Polsce i w Austrii². Potencjalnym ograniczeniem jest tutaj możliwość nieintencjonalnego pominięcia materiału prasowego bądź też pominięcia materiału, który wyemitowano na żywo przez radio lub telewizję, lecz nie został utrwalony przez narzędzie monitorujące media lub $\mathrm{w}$ internecie.

\section{Metodologia}

Przyjmuję, że dyskurs to ciąg zachowań językowych, powiązanych tematem, celem i sposobem ukształtowania wypowiedzi; temat, sposób i cel warunkują zaś i zarazem są warunkowane przez styl, gatunek tekstu oraz sytuację komunikacyjną ${ }^{3}$. Dyskurs zakłada istnienie wzorców i wspólnych cech w ramach wiedzy i struktur, przy czym tekst jest konkretną i unikatową realizacją dyskursu ${ }^{4}$. Teksty należą do gatunków, czyli społecznie akceptowalnych sposobów użycia języka w powiązaniu z konkretnym typem działania społecznego ${ }^{5}$. W tym przypadku są to artykuły prasowe i internetowe oraz audycje w radiu i telewizji. Przeanalizowałam zebrane materiały w oparciu o metodę zaproponowaną przez amerykańskiego teoretyka dyskursu, Jamesa Paula Gee ${ }^{6}$. Wyróżnił on siedem poziomów analizy dyskursu:

1. Znaczenie (ang. significance) - w jaki sposób dana wypowiedź jest używana, aby nadać określonym rzeczom znaczenie lub go ich pozbawić?

2. Czynności (ang. activities) - jakie działania podkreśla dana wypowiedź?

3. Tożsamości (ang. identities) - jaki rodzaj tożsamości sugeruje dana wypowiedź?

4. Relacje (ang. relationships) - jakie relacje z innymi podmiotami sugeruje/buduje ta wypowiedź? Jak sytuuje innych w stosunku do siebie i siebie w stosunku do innych?

5. Polityka (ang. politics, the distribution of social goods) - jakie przymioty ludzie, podmioty państwowe i prywatne chciałyby posiadać, co jest dla nich wartościowe? Jaką ocenę tych ludzi i podmiotów sugeruje wypowiedź w kategoriach charakteru, reputacji, praw, obowiązków, winy, odpowiedzialności czy motywów?

6. Połączenia (ang. connections) - czy wypowiedź sugeruje związek lub brak związku między rzeczami; czy sugeruje, że są one dla siebie ważne lub nieważne?

2 Uzyskałam dostęp do elektronicznych wycinków, a także nagrań audycji radiowych i telewizyjnych w badanym okresie, tj. między 1 kwietnia a 30 czerwca 2017 roku, od następujących firm monitorujących media, odpowiednio: w Polsce: Instytut Monitorowania Mediów, w Austrii: Meltwater i ORF. Nie uwzględniono depesz Informacyjnej Agencji Radiowej, nieobjętych monitoringiem wymienionych firm.

3 E. Laskowska, Dyskurs parlamentarny w ujęciu komunikacyjnym, Wydawnictwo Akademii Bydgoskiej im. Kazimierza Wielkiego, Bydgoszcz 2004, s. 14.

${ }_{4}$ R. Wodak, M. Krzyżanowski (red.), Jakościowa analiza dyskursu w naukach spolecznych, Wydawnictwo Akademickie Oficyna Wydawnicza Łośgraf-Wiesław Łoś, Warszawa 2011, s. 18.

5 Ibidem, s. 29.

6 J.P. Gee, An Introduction to Discourse Analysis: Theory and Method, Routledge, London-New York 2005, s. 11-13. 
7. Systemy znaków i wiedza (ang. sign system and knowledge) - w jaki sposób dana wypowiedź preferuje jeden $\mathrm{z}$ hermetycznych, właściwych dla danej grupy systemów komunikacji, bądź jeden z systemów przekonań albo wiary?

Przyjrzałam się również, czy treści dotyczące obchodów rocznicy wyzwolenia obozu Gusen były dobierane ze względu na kryteria wartości informacyjnej?

\section{Specyfika mediów polskich i austriackich}

Wśród polskich mediów, które informowały o obchodach 72. rocznicy wyzwolenia obozu Gusen, dominowały Polska Agencja Prasowa i media publiczne, które w Polsce - ze względu na sposób wyboru ich władz - w pozytywnym świetle przedstawiają politykę historyczną prowadzoną przez $\mathrm{rząd}^{8}$. Austriacka agencja prasowa - Austria Presse Agentur (APA), jest przedsiębiorstwem spółdzielczym austriackiej prasy i radia, dzięki czemu pozostaje niezależna9. Jej neutralne materiały są następnie rozwijane przez poszczególnych wydawców zgodnie z indywidualną linią redakcyjną. O wydźwięku artykułu często decydują tytuł i towarzyszące mu zdjęcie, w przypadku mediów audiowizualnych - dobór osoby komentującej. Można stwierdzić, że publiczny nadawca ORF do pewnego stopnia też odzwierciedla sympatie partii rządzących ${ }^{10}$.

Tzn. czy spełniały następujący zestaw cech: czy były możliwie aktualne (dotyczyły czegoś, co właśnie trwa); dotyczyły negatywnych zjawisk (konfliktu, katastrofy, ofiar); czy były zaskakujące (dotyczyły czegoś, co się jeszcze nigdy nie zdarzyło); czy opisywane zjawiska miały ogromna skalę czy natężenie; czy przebieg wydarzeń, sens zjawisk i ich ocena aksjologiczna były jednoznaczne (dobre albo złe); czy opisywane wydarzenia były bliskie kulturowo lub geograficznie dla odbiorców; czy wiadomości były spersonalizowane (dotyczyły jednostek i ich zachowań, nie procesów, analizy zjawisk, problemów ogólnych); czy zdarzenia i osoby mogły wpływać na życie odbiorców; czy opis zjawisk odpowiada oczekiwaniom odbiorców, zwłaszcza panującym wśród nich potocznym przekonaniom i stereotypom; czy zdarzenia wynikały z logicznego rozwoju sytuacji i były przewidywalne; czy opisywane zdarzenia stanowiły kontynuację czegoś, o czym media wcześniej już donosiły; czy wiadomości dotyczyły elit ekonomicznych, społecznych, kulturalnych; czy wiadomości były konkretne (zawierały nazwiska, daty, nazwy); czy wiadomości pochodziły z wiarygodnych źródeł (od osób, które można określić jako kompetentne, dobrze poinformowane, godne zaufania); czy wiadomości wzbogacały i uatrakcyjniały tematykę pojawiającą się w danym medium; czy wiadomości pojawiły się w danym medium na zasadzie wyłączności. Por. M. Lisowska-Magdziarz, Analiza tekstu w dyskursie medialnym. Przewodnik dla studentów, Wydawnictwo Uniwersytetu Jagiellońskiego, Kraków 2006, s. 96-97.

8 W Polsce sposób powoływania władz mediów publicznych regulują ustawy: Ustawa z dnia 22 czerwca 2016 r. o Radzie Mediów Narodowych; Ustawa z dnia 31 lipca 1997 r. o Polskiej Agencji Prasowej; Ustawa z dnia 29 grudnia 1992 r. o radiofonii i telewizji.

9 Blisko połowa APA należy do nadawcy publicznego ORF, pozostałe udziały ma 12 austriackich wydawców prasy.

10 Sposób kontroli nadawcy publicznego regulują ustawy: Bundesgesetz vom 12. Juni 1981 über die Presse und andere publizistische Medien (Ustawa medialna), Bundesgesetz über den Österreichischen Rundfunk z 5 lipca 2001 roku (Ustawa ORF) oraz Bundesgesetz über die Einrichtung einer Kommunikationsbehörde Austria (KommAustria) und eines Bundeskommunikationssenates z 30 marca 2001 roku (Ustawa powołująca KommAustria). Głównym ciałem nadzorującym działalność ORF jest Urząd ds. Komunikacji Austrii (KommAustria), które to gremium składa 


\section{Przekaz w mediach polskich}

W badanym okresie w polskich mediach doniesienia o Austrii w szerokim ujęciu pojawiały się w różnych kontekstach i miały w ogromnej większości wydźwięk neutralny lub negatywny. Opisywano zbliżające się wybory parlamentarne w Austrii, pojawiały się sylwetki Sebastiana Kurza jako potencjalnego przyszłego kanclerza, podkreślające jego młody wiek i konserwatywne poglądy. Pisano również o grożącym Austrii - podobnie jak Polsce - postępowaniu w Komisji Europejskiej za odmowę przyjęcia uchodźców, a przy tej okazji opisywano przypadki przestępstw popełnianych przez imigrantów lub uchodźców na terenie Austrii. Innymi tematami dotyczącymi Austrii były: postępowanie Komisji Europejskiej wobec Austrii dotyczące przepisów o płacy minimalnej w transporcie międzynarodowym oraz poparcie Austrii dla budowy gazociagu Nord Stream 2, któremu strona polska jest przeciwna. Pozytywnie opisywano możliwy udział Austrii w inicjatywie Trójmorza. Pojawiły się też wzmianki o obchodach świąt 1 i 3 maja, organizowanych przez Polonię w Austrii.

Najwięcej materiałów na temat obchodów 72. rocznicy wyzwolenia obozu Gusen przygotowała Polska Agencja Prasowa (PAP) ${ }^{11}$. Stanowiły one podstawowy materiał źródłowy dla większości polskich mediów, publicznych i prywatnych. Warto podkreślić, że prywatne telewizje informacyjne (Polsat News, TVN24, TVN BiŚ, Superstacja) nie przygotowały relacji telewizyjnych z uroczystości. Na swoich stronach internetowych przedrukowywały jedynie depesze i zdjęcia za PAP.

Z depesz przebija silne przeciwstawienie ,złych” władz Austrii na szczeblu centralnym „dobrej” społeczności lokalnej. Jest to widoczne w wypowiedziach przedstawicieli polskich władz: Jana Dziedziczaka, ówczesnego sekretarza stanu w Ministerstwie Spraw Zagranicznych; Magdaleny Gawin, podsekretarz stanu w Ministerstwie Kultury i Dziedzictwa Narodowego, jak również Roberta Kostro, dyrektora Muzeum Historii Polski; Dariusza Pawłosia, przewodniczącego zarządu Fundacji „Polsko-Niemieckie Pojednanie", i ambasadora RP w Wiedniu Artura Lorkowskiego.

się z pięciu członków mianowanych przez prezydenta na wniosek rządu federalnego na kadencję trwającą sześć lat. Urząd odpowiada też za nadzór nad działalnością prywatnych nadawców radiowych i telewizyjnych. W strukturze ORF jednym z dwóch gremiów kontrolnych jest Rada Założycielska (Stiftungsrat), która składa się z 35 członków mianowanych przez rząd federalny (dziewięciu członków), kraje związkowe (dziewięciu członków, po jednym członku z każdego kraju), Radę Publiczności (sześciu członków) i Centralną Radę Zakładową ORF (pięciu członków). Ponadto rząd federalny mianuje kolejnych sześciu członków, biorąc pod uwagę propozycje partii politycznych reprezentowanych w Radzie Narodowej, czyli w izbie niższej austriackiego parlamentu. Kadencja Rady Założycielskiej trwa cztery lata, a jej głównym zadaniem jest mianowanie i odwołanie dyrektora generalnego ORF. Obok Rady Założycielskiej, drugim gremium nadzorczym w ORF jest Rada Publiczności, która reprezentuje interesy słuchaczy i widzów ORF, poprzez reprezentantów rekrutujących się ze środowisk naukowych i kulturalnych. Więcej o krajobrazie medialnym Austrii w publikacji Urzędu Kanclerskiego zob.: Medien in Österreich (dostęp online: http://archiv.bundeskanzleramt.at/DocView.axd?CobId=57669); M. Jas-Koziarkiewicz, Austria, w: E. Stasiak-Jazukiewicz, M. Jas-Koziarkiewicz (red.), Polityka medialna w Unii Europejskiej, Wydawnictwo Poltext, Warszawa 2011, s. 124-125.

11 Analizowane były jedynie własne depesze PAP, nie zaś nadesłane. 


\begin{tabular}{|l|l|}
\hline \multicolumn{2}{|c|}{ Depesze opublikowane przez PAP w badanym okresie } \\
\hline 3 maja 2017 & W PE otwarto wystawę poświęconą obozowi w Gusen \\
\hline 5 maja 2017 & $\begin{array}{l}72 \text { lata temu wyzwolony został niemiecki obóz Mauthausen-Gusen } \\
- \text { miejsce śmierci tysięcy Polaków }\end{array}$ \\
\hline 6 maja 2017 & $\begin{array}{l}\text { Polska delegacja na obchodach 72. rocznicy wyzwolenia niemieckiego } \\
\text { obozu Mauthausen-Gusen }\end{array}$ \\
\hline 6 maja 2017 & $\begin{array}{l}\text { Magdalena Gawin: liczymy, że władze austriackie wykażą dobrą wolę } \\
\text { ws. obozu Gusen }\end{array}$ \\
\hline 7 maja 2017 & $\begin{array}{l}\text { Polska delegacja na obchodach 72. rocznicy wyzwolenia obozu } \\
\text { Mauthausen }\end{array}$ \\
\hline 7 maja 2017 & $\begin{array}{l}\text { Gawin: chcielibyśmy w obozie w Gusen zachować od zniszczenia to, } \\
\text { co można }\end{array}$ \\
\hline 8 maja 2017 & $\begin{array}{l}\text { Austria/ Wiceszef MSZ spotkał się w Wiedniu z b. więźniami obozu } \\
\text { Mauthausen-Gusen oraz Polonią }\end{array}$ \\
\hline 8 maja 2017 & $\begin{array}{l}\text { Wiceminister Gawin o stanowisku austriackiego MSW } \\
\text { ws. upamiętnienia obozu w Gusen }\end{array}$ \\
\hline 8 maja 2017 & $\begin{array}{l}\text { Austria/ Dziedziczak: przez likwidację polskiej elity miał być zniszczony } \\
\text { naród }\end{array}$ \\
\hline 9 maja 2017 & $\begin{array}{l}\text { Austria/ Zakończyła się konferencja o zagładzie polskiej i europejskiej } \\
\text { inteligencji }\end{array}$ \\
\hline 11 maja 2017 & $\begin{array}{l}\text { Wiceminister Gawin i sejmowa komisja kultury o ochronie } \\
\text { KL Mauthausen-Gusen }\end{array}$ \\
\hline
\end{tabular}

Z ich wypowiedzi dla mediów rysuje się obraz, w którym władze Austrii nie chca wykupić terenu, gdzie znajdują się pozostałości po obozie, wykazują przeciwdziałanie i niechęć w stosunku do Polski, deklarują ogólniki w rozmowach z Polska, nie edukują młodego pokolenia Austriaków o wydarzeniach w Gusen (brak informacji o Gusen w podręcznikach do historii), nie uznają wyjątkowości Gusen dla Polaków, przedstawiając Gusen jako miejsce równorzędnej kaźni 27 narodów. ,[...] zdaniem [R. Kostro] władze austriackie ciagle robią za mało, by chronić to miejsce pamięci. »Nie może być tak, że wszystkie działania są podejmowane $\mathrm{z}$ inicjatywy więźniów, społecznego komitetu albo państwa polskiego. To jest także obowiązek władz austriackich« - powiedział. Kostro uważa, że wszelkie obiekty dawniej wchodzące w skład obozu powinny być objęte ochroną konserwatorską" ${ }^{2}$. „Po wojnie, na miejsce upamiętnienia działających na terenie Austrii obozów zaadaptowany został obóz w Mauthausen. Pozostałości po KL Gusen zostały w znacznej części zniszczone, zaś tereny poobozowe - podzielone i sprzedane prywatnym właścicielom, co doprowadziło w konsekwencji do powstania na obszarze dawnego obozu zabudowy mieszkalnej oraz zakładów przemysłowych. Przed wyjazdem na niedzielne uroczystości wiceminister Gawin mówiła PAP m.in., że strona polska czeka na wykupienie terenu byłego obozu koncentracyjnego Gusen z rąk prywatnych przez

12 Depesza PAP, W PE otwarto wystawe poświęconq obozowi w Gusen, data publikacji: 3 maja 2017. 
władze austriackie. »Liczymy na to, że wykażą dobrą wolę« - dodała”13. „Jak podkreśliła [wiceminister Gawin], strona austriacka sprzeciwia się aktywności polskiej, argumentując, że obóz Mauthausen-Gusen to miejsce męczeństwa przedstawicieli 27 narodowości. Zgodnie z tą argumentacja, dodała: »Polakom odbiera się prawo do konsultacji i upamiętniania tego miejsca, bo liczba i narodowość ofiar także podobno nie ma znaczenia «"14. „»Liczymy na to, że władze austriackie będą chciały z nami podjąć dialog; dotychczasowe rozmowy sa $\mathrm{w}$ zasadzie jednostronne - powiedziała w poniedziałek wiceminister kultury i dziedzictwa narodowego Magdalena Gawin, nawiązując do stanowiska austriackiego MSW ws. jej wypowiedzi nt. upamiętnienia obozu w Gusen. »Od czerwca ubiegłego roku toczą się rozmowy, które są w zasadzie rozmowami jednostronnymi, wszystkie spotkania, wszystkie telefony zostały wykonane przez stronę Polska, natomiast, o ile się nie mylę, dialog polega na tym, że chcą rozmawiać obie strony« powiedziała”" „Dariusz Pawłoś z Fundacji Polsko-Niemieckie Pojednanie powiedział, że przyszłością miejsca - gdzie kiedyś znajdował się obóz - jest stworzenie tam Europejskiego Centrum Edukacyjnego im. Henryka Sławika. »Taką propozycję złożyliśmy stronie austriackiej i mamy nadzieję, że wraz ze społecznością lokalną - co do której jesteśmy pewni, że jest po naszej stronie - wspólnymi siłami przekonamy władze wiedeńskie do tego, że takie centrum jak najszybciej powinno tam powstać« - stwierdził Pawłoś. [Wiceminister] Gawin dodała, że strona polska współpracuje z lokalnym środowiskiem ws. upamiętnienia obozu w Gusen. Podkreśliła, że powołana została inicjaty-

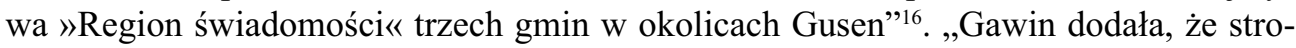
na polska współpracuje z lokalnym środowiskiem ws. upamiętnienia obozu w Gusen. »Mamy znakomitą współpracę z lokalnym środowiskiem, które naprawdę bardzo podziwiamy« - stwierdziła. Podkreśliła, że powołana została inicjatywa »Region świadomości« trzech gmin w okolicach Gusen. »To, co nas bardzo pozytywnie zaskoczyło, to to, że mieszkańcy tego miejsca, którzy dowiedzieli się już jako osoby dorosłe, że żyją na terenie obozu koncentracyjnego, podejmują taki wysiłek. Chciałyby, żeby to miejsce wyglądało jak miejsce pamięci, a nie jak śmietnik, i to budzi nasz absolutny podziw, jesteśmy im za to wdzięczni« - dodała" ${ }^{17}$., [Ambasador Polski w Wiedniu Artur Lorkowski] Pytany, czy mieszkańcy Gusen mają świadomość, że znajdował się tam obóz, odpowiedział, że tak. »Te osoby stały się dla nas bardzo ważnymi partnerami, z którymi odkrywamy historię tego obozu - obozu, który miał być zapomniany, ale stopniowo fizycznie jest odkopywane to, co zostało zasypane, ale również i w głowach następuje odświeżanie tej pamięci i to jest bardzo pozytywne «-mówił"18.

13 Depesza PAP, Polska delegacja na obchodach 72. rocznicy wyzwolenia niemieckiego obozu Mauthausen-Gusen, data publikacji: 6 maja 2017.

14 Depesza PAP, Magdalena Gawin: liczymy, że władze austriackie wykaża dobra wole ws. obozu Gusen, data publikacji: 7 maja 2017.

15 Depesza PAP, Wiceminister M. Gawin o stanowisku austriackiego MSW ws. upamiętnienia obozu w Gusen, data publikacji: 8 maja 2017.

16 Depesza PAP, Wiceminister Gawin i sejmowa komisja kultury o ochronie KL Mauthausen-Gusen, data publikacji: 11 maja 2017.

17 Depesza PAP, Gawin: chcielibyśmy w obozie w Gusen zachować od zniszczenia to, co można, data publikacji: 7 maja 2017.

18 Ibidem. 
$\mathrm{W}$ depeszach PAP, podobnie jak w omówionych niżej pozostałych przekazach medialnych, mamy też do czynienia z jednostronnym opisem współczesnego terenu, na którym znajdował się obóz. Jest on „podzielony”, „zniszczony”, „rozgrabiony”, „przekształcony”, „zdewastowany”. W depeszach słabo zaznaczono informację o planach powołania na terenie byłego obozu Europejskiego Centrum Edukacyjnego im. Henryka Sławika. Nie wspomniano o tym, że od lipca 1945 do maja 1955 roku teren obozu Gusen znajdował się pod okupacją sowiecką i został już wtedy mocno zniszczony i rozgrabiony.

Doniesienia radiowe i telewizyjne o obchodach 72. rocznicy wyzwolenia obozu Gusen pojawiły się w Programie I Polskiego Radia (7 maja 2017), w Radiu Maryja (8 maja 2017), w radiu Tok FM (5 maja 2017 i 8 maja 2017), w Telexpressie TVP (8 maja 2017) i Wiadomościach TVP (8 maja 2017). Wyemitowano również dwa wywiady o uroczystościach $\mathrm{z}$ wiceminister Magdaleną Gawin: telewizyjny w audycji „Gość Poranka” TVP Info (5 maja 2017) oraz radiowy w audycji „Gorący temat” Polskiego Radia 24 (5 maja 2017). Polskiemu Radiu 24 (8 maja 2017) wywiadu udzielił też sekretarz Międzynarodowej Rady Oświęcimskiej Marek Zając, jeden ze współtwórców pomysłu powołania Europejskiego Centrum Edukacji im. Henryka Sławika i autor wystawy przygotowanej przez Muzeum Historii Polski „Gusen: granit i śmierć, pamięć i zapomnienie". W Radiu Wnet (12 maja 2017) wyemitowano wywiad z Rafałem Sobczakiem, dyrektorem Instytutu Polskiego w Wiedniu. Opowiedział on obszernie o dwudniowej konferencji „Zabijanie inteligencji. Europejskie elity intelektualne pod okupacją niemiecka, 1939-1945", organizowanej z okazji obchodów 72. rocznicy wyzwolenia KL Gusen przez Instytut Polski wspólnie z Ośrodkiem Badań nad Totalitaryzmami im. Witolda Pileckiego, MSZ oraz MKiDN. Mówił też o zabiegach strony polskiej o upamiętnienie pozostałości po KL Gusen, w tym o objęciu byłego placu apelowego ochroną konserwatorską. Informacyjna Agencja Radiowa zarejestrowała wypowiedzi potomków więźniów obozu Gusen, którzy wzięli udział w uroczystościach ${ }^{19}$.

$\mathrm{W}$ prasie drukowanej i wydaniach internetowych gazet pojawiło się kilka artykułów na temat Gusen, przede wszystkim udzielających głosu byłym więźniom i przedstawicielom władz Polski, mówiącym o bieżącej sytuacji na terenie byłego obozu na tle jego historii.

\begin{tabular}{|c|c|}
\hline \multicolumn{2}{|c|}{$\begin{array}{l}\text { Artykuły nt. Gusen w kontekście obchodów 72. rocznicy wyzwolenia obozu } \\
\text { w polskiej prasie }\end{array}$} \\
\hline $\begin{array}{l}\text { „Tygodnik Powszechny”, } \\
26 \text { marca } 2017^{\mathrm{a}}\end{array}$ & Bitwa o Gusen, P. Bukalska \\
\hline $\begin{array}{l}\text { strona telewizjarepublika.pl, } \\
5 \text { maja } 2017\end{array}$ & $\begin{array}{l}\text { Dziś rocznica wyzwolenia bytego niemieckiego obozu } \\
\text { zagłady Mauthausen-Gusen, w którym masowo } \\
\text { mordowano Polaków }\end{array}$ \\
\hline
\end{tabular}

19 IAR, Do miejsca kaźni tysięcy osób, w tym wielu naszych rodaków, przyjechaty tė zorganizowane grupy z calej Polski, data emisji: 7 maja 2017, https://www.polskieradio.pl/5/3/Artykul/ 1761933,Polska-delegacja-na-obchodach-72-rocznicy-wyzwolenia-obozu-MauthausenGusen (dostęp: 15 kwietnia 2018). 


\begin{tabular}{|l|l|}
\hline „Rzeczpospolita”, 5 maja 2017* & Zachować pamięć o obozie KL Gusen, J. Ćwiek \\
\hline „Super Express”, 6 maja 2017* & $\begin{array}{l}\text { Chronmy obóz w Gusen - to miejsce eksterminacji } \\
\text { polskiej inteligencji (rozmowa z wiceminister M. Gawin) }\end{array}$ \\
\hline „Nasz Dziennik”, 9 maja 2017* & Kruszenie niepamięci, P. Falkowski \\
\hline $\begin{array}{l}\text { strona DoRzeczy.pl, 15 maja } \\
2017\end{array}$ & $\begin{array}{l}\text { Austria wciaż obojętna wobec śmietnika na terenie } \\
\text { KL Gusen, P. Włoczyk }\end{array}$ \\
\hline „W Sieci”, 15 maja 2017 & $\begin{array}{l}\text { Przywrócić pamięć o Gusen, A. Skwarczyński } \\
\text { (rozmowa z wiceminister M. Gawin) }\end{array}$ \\
\hline $\begin{array}{l}\text { strona rp.pl/historia, 18 maja } \\
2017\end{array}$ & Zachować pamięć o Gusen, M. Kozubal \\
\hline „Rzeczpospolita”, 19 maja 2017 & Zachować pamięć o Gusen, M. Kozubal \\
\hline
\end{tabular}

a Jest to tygodnik, zatem data obowiązywania wydania obejmuje tydzień, począwszy od daty na okładce, i tym samym mieści się w badanym okresie (26 marca - 2 kwietnia 2017).

* Wydanie internetowe artykułu ukazało się tego samego dnia, pod tym samym tytułem.

Warto zaznaczyć, że media polskie nie stosują jednolitego nazewnictwa dotyczącego obozu Gusen, mówiąc np. o „Mauthausen i KL Gusen”, „KL Mauthausen-Gusen” czy „,niemieckim nazistowskim obozie systemu Mauthausen-Gusen" ${ }^{20}$.

W mediach polskich dominującym przekazem o samym KL Gusen był fakt, że było to miejsce planowej eksterminacji polskiej inteligencji przez Rzeszę Niemiecką. „Ocalało tylko krematorium wykupione przez byłych więźniów. To jedyne miejsce upamiętnienia kaźni 35 tysięcy Polaków. W Gusen Niemcy prowadzili z rozmysłem eksterminację polskiej inteligencji” ${ }^{21}$. „KL Gusen było jednym z najcięższych obozów koncentracyjnych w całym systemie obozów III Rzeszy i największym na terenie Austrii. To miejsce wyjątkowe, symbol eksterminacji polskich elit intelektualnych podczas niemieckiej okupacji. To przejmujące świadectwo nazistowskiego totalitaryzmu - powiedziała Podsekretarz Stanu w MKiDN prof. Magdalena Gawin”22.

W polskich mediach dominowały informacje o obchodach przy Memoriale Gusen (5-6 maja) i wydarzenia w polskich placówkach dyplomatycznych - ambasadzie i Instytucie Polskim (7-9 maja). „W Linzu w Austrii rozpoczną się uroczystości związane

20 Po stronie polskiej brak konsekwencji w stosowaniu nazwy obozu koncentracyjnego Gusen. W ostatnich latach KL Gusen coraz częściej występuje jako odrębny obóz, o swojej indywidualnej historii i specyfice. Trudno wymagać, by dziennikarze stosowali właściwą nazwę „KL Gusen”, skoro dwie instytucje w Polsce, które odgrywają centralną rolę w tworzeniu komunikatów o Gusen, używają zróżnicowanych określeń. Tytuły informacji prasowych nt. dorocznych uroczystości rocznicowych publikowane przez Ministerstwo Spraw Zagranicznych oraz tytuły artykułów o Gusen w dziale „Aktualności” na stronie Ministerstwa Kultury i Dziedzictwa Narodowego zawierają nieujednolicone, zróżnicowane wersje nazewnictwa KL Gusen.

21 Wiadomości TVP, wydanie główne, Przywrócić pamięć, data emisji: 8 maja 2017.

22 Dziś rocznica wyzwolenia bylego NIEMIECKIEGO obozy zagłady Mauthausen-Gusen, w którym masowo mordowano POLAKÓW!, data publikacji: 5 maja 2017, http://telewizjarepublika. $\mathrm{pl}$ /dzis-rocznica-wyzwolenia-bylego-niemieckiego-obozy-zaglady-mauthausen-gusen-w-ktorymmasowo-mordowano-polakow,48106.html (dostęp: 15 kwietnia 2018). 
z 72. rocznicą wyzwolenia niemieckich nazistowskich obozów koncentracyjnych systemu Mauthausen-Gusen. Wezmą w nich udział przedstawiciele polskich władz, m.in. wiceminister spraw zagranicznych Jan Dziedziczak i wiceminister kultury Magdalena Gawin, towarzyszący delegacji organizacji byłych więźniów oraz organizacji kombatanckich. Uroczystości przy Memoriale Gusen, przy pomniku, przy którym wezmą udział prezydent Austrii Alexander van der Bellen, odbędą się w sobotę, czyli jutro"23.

$\mathrm{O}$ centralnych, międzynarodowych uroczystościach przy Memoriale Mauthau$\operatorname{sen}^{24}$ (7 maja) była mowa przede wszystkim w polskim kontekście. „Przed południem w Austrii na terenie Mauthausen i KL Gusen polska delegacja weźmie udział w centralnych uroczystościach 72. rocznicy oswobodzenia nazistowskich obozów zagłady. Niedzielne uroczystości organizowane są przez Polski Instytut w Wiedniu i Fundację »Polsko-Niemieckie Pojednanie« oraz władze lokalne"25. „W niedzielę natomiast delegacja uczestniczyła w centralnych uroczystościach 72. rocznicy wyzwolenia obozu KL Mauthausen, gdzie złożyła kwiaty na placu apelowym i wzięła udział w uroczystej mszy świętej”26.

W relacjach można dostrzec podkreślanie udziału polskiej delegacji, w tym wiceministrów oraz polskich więźniów, harcerzy i uczniów, niewiele uwagi poświęca się natomiast udziałowi władz lokalnych gmin, na terenie których znajdował się obóz Gusen, oraz prezydenta Republiki Austrii Alexandra Van der Bellena. „Ocalonym i tym, których zgładzono, polskie władze, harcerze i uczniowie oddali hołd”27. „Mój pradziadek był w tym obozie Mauthausen trzy miesiące i właśnie nosił te kamienie. I dla mnie, jak widzę te pomniki, bo to nawet tragicznym nie można nazwać, co się tutaj działo. To był najcięższy z obozów na świecie, jaki był w czasie drugiej wojny światowej”28. „Niedzielne uroczystości organizowane są przez Polski Instytut w Wiedniu i Fundację »Polsko-Niemieckie Pojednanie« oraz władze lokalne"29.

$\mathrm{W}$ mediach lakonicznie w stosunku do rangi wydarzenia zostało potraktowane też samo przemówienie prezydenta Austrii przy KL Gusen, w którym mówił, że inicjatywy na rzecz upamiętnienia Gusen będą wspierane zarówno przez Republikę Austrii, jak i przez inicjatywy regionalne oraz partnerów międzynarodowych przy udziale społeczeństwa obywatelskiego ${ }^{30}$. Jeden z dzienników odnotował: „Kilka dni temu w Gusen odbyły się uroczystości związane z 72. rocznicą wyzwolenia obozu. Po raz pierwszy

\footnotetext{
23 Tok FM, „Pierwsze Śniadanie w TOK-u”, data emisji: 5 maja 2017.

24 „Obóz koncentracyjny Gusen był oddziałem zamiejscowym (Unterkunft) lub podobozem $(\mathrm{Ne}$ benlager) obozu koncentracyjnego Mauthausen, który stanowił centralę całego systemu obozów położonych na terenie Austrii. Sieć podobozów liczyła 101 jednostek w 83 miejscowościach. W latach 1941-1942 Gusen był największym podobozem w Austrii, większym niż macierzyste Mauthausen". Cyt. za: S. Dobosiewicz, Mauthausen-Gusen - obóz zagłady, Wydawnictwo Ministerstwa Obrony Narodowej, Warszawa 1977, s. 9.

25 Program 1 Polskiego Radia, „Wiadomości”, data emisji: 7 maja 2017.

26 Depesza PAP, Austria/ Wiceszef MSZ spotkat się w Wiedniu z b. więźniami obozu MauthausenGusen oraz Poloniq, data publikacji: 8 maja 2017.

27 Wiadomości TVP, wydanie główne, Przywrócić pamięć...

28 IAR, Do miejsca kaźni tysięcy osób...

29 Program 1 Polskiego Radia, „Wiadomości”, data emisji: 7 maja 2017.

30 Tłumaczenie przemówienia prezydenta Republiki Austrii zob. s. 185-188.
} 
w historii uczestniczył w nich prezydent Austrii Alexander Van der Bellen" ${ }^{\text {"1 }}$. Obszerniej przypomniały o tym tylko komunikaty prasowe na stronach MKiDN z 5 maja 2017 („Obecność Alexandra Van der Bellena była wydarzeniem bez precedensu, nigdy wcześniej tak wysoki ranga przedstawiciel władz austriackich nie był obecny na oficjalnych obchodach w tym miejscu"32) oraz Urzędu do Spraw Kombatantów i Osób Represjonowanych (,W niedzielnych uroczystościach uczestniczyli również prezydent Austrii Alexander Van der Bellen [...]"33).

Jeśli chodzi o sposób przedstawiania społeczności lokalnej, uwidacznia się sympatia dla jednostek zaangażowanych w proces upamiętniania Gusen. Społeczność lokalna zamieszkująca okolice obozu, która współpracuje z Polską na rzecz upamiętnienia historii obozu, jest przedstawiana w opozycji do władz austriackich, ale i anonimowych ludzi, którzy bezrefleksyjnie zamieszkują teren poobozowy. Wiadomości TVP wykorzystały wypowiedź Marthy Gammer, odznaczonej podczas uroczystości za działalność na rzecz upamiętnienia Gusen orderem Zasłużony dla Kultury Polskiej: „Austriackie władze muszą wykupić teren. [wiceminister M. Gawin:] »Na pewno nie zrezygnujemy z tego, żeby to było prawdziwe miejsce upamiętnienia, a nie śmietnik«. O co zabiegają też mieszkańcy Gusen. Oni nie uciekają przed historią. Trzy osoby, wśród nich Martha Gammer, otrzymały od wiceminister kultury odznaczenia za swoja pracę na rzecz przywracania pamięci o tym miejscu. [M. Gammer:] »Jeden z moich uczniów sam zaczął badać dokładnie, co tu się działo. Rozmawiał z miejscowymi, przyszedł z tym do mnie. Historia, która musi być opowiedziana, nie może zostać wymazana «" ${ }^{34}$. „Istnieje na pewno uczciwość zwykłych ludzi, zwłaszcza tam na miejscu, w Gusen. Chcemy im to wynagrodzić, choćby symbolicznie. Trzy osoby z lokalnego stowarzyszenia otrzymają odznaczenia Zasłużony dla Kultury Polskiej, choć zasługuje na to więcej osób”35. „Zabudowanie tego terenu nie jest winą ludzi tam mieszkających, ale władz, które im na to pozwoliły. Przecież Austria od połowy lat 50. była już wolnym krajem”"36., ,[Rudolf] Haunschmied [...] poświęcił się zapisywaniu historii obozu. W latach 80 . był współzałożycielem stowarzyszenia, które miało zbierać informacje o obozie i działać dla upamiętnienia jego ofiar [...]. Odtąd Haunschmied wraz z innymi mieszkańcami - w tym Marthą Gammer - ratuje, co może. W 2009 r. udało im się powstrzymać całkowite zalanie betonem Bergkristall ${ }^{37}$. W 2005 r. doprowadzili do powstania autoprzewodnika po Gusen,

\footnotetext{
31 M. Kozubal, Zachować pamięć o Gusen, „Rzeczpospolita”, 19 maja 2017, s. A4.

32 Obchody 72. rocznicy wyzwolenia bylego niemieckiego obozu koncentracyjnego MauthausenGusen, data publikacji: 5 maja 2017, http://www.mkidn.gov.pl/pages/posts/obchody-72.-rocznicywyzwolenia-bylego-niemieckiego-obozu-koncentracyjnego-mauthausen-gusen-7351.php (dostęp: 15 kwietnia 2018).

33 72. rocznica wyzwolenia KL Mauthausen-Gusen, http://kombatanci.gov.pl/en/2-aktualno \%C5\%9Bci/749-72-rocznica-wyzwolenia-kl-mauthausen-gusen.html (dostęp: 15 kwietnia 2018).

34 Wiadomości TVP, wydanie główne, Przywrócić pamięć...

35 A. Skwarczyński, Przywrócić pamięć o Gusen, „W Sieci”, 15 maja 2017, s. 86-88.

36 Ibidem.

37 System sztolni „Bergkristall“ w St. Georgen/Gusen należy do największych obiektów budowlanych z czasów narodowego socjalizmu na terenie Austrii. W latach 1944-1945, w ciagu zaledwie trzynastu miesięcy, więźniowie obozu koncentracyjnego Gusen II wybudowali sztolnie,
} 
stworzonego przez miejscowych artystów. Ale najbardziej przełomowe było w ich pracy zorganizowanie uroczystości w Gusen w 1995 r., w których wzięli udział mieszkańcy i byli więźniowie”38. „Dopiero w 1997 r. Austria uznaje pomnik w Gusen jako oficjalne miejsce pamięci. Po ponad 50 latach od wyzwolenia byli więźniowie zyskują prawo do upamiętnienia miejsca swego cierpienia. Trzeba podkreślić, że nie udałoby się to, gdyby nie wysyłki również mieszkańców, którzy od lat 80 . zaczęli wspierać więźniów i zabiegać o pamięć o obozie” 39 . „Dużo dzieje się na poziomie lokalnym, co widać też w Gusen” ${ }^{40}$. „Wiceminister zwraca także uwagę na to, że w Austrii o zachowanie pamięci o obozie zagłady dbają przede wszystkim mieszkańcy, a nie tamtejsze władze" „Wielu mieszkańców Gusen jest bardzo przyjaźnie nastawionych do Polaków, chcą upamiętnienia tego miejsca, walczą o to od wielu lat. Sami dowiedzieli się, że mieszkają na terenie obozu, późno. Milczały na ten temat podręczniki. Nasze oraz ich dążenia spotykają się z przeciwdziałaniem władz austriackich i wyraźną niechęcią"42.

Reszta członków społeczności lokalnej - ci niezainteresowani historią swojego miejsca - to anonimowi „ludzie” mieszkający w budynkach poobozowych, posiadający teren po obozie jako własność prywatną. „Plac apelowy w Mauthausen to miejsce-symbol i jeden z niewielu śladów po zbrodni. [S. Zalewski:] »Austriacy zacierają jak mogą«, przypomina pan Stanisław, bo obóz Gusen, w którym przeszedł piekło, dziś wygląda tak. Po wojnie baraki sprzedano, przerobiono na domy. Mieszkają w nich ludzie. W tej willi też, a to przecież brama wjazdowa do obozu”43. „Sądzę, że właściciele [willi z bramą wjazdową do byłego obozu] nie widzą w swoim zachowaniu żadnego problemu. To ich własność"

Z kolei „władze austriackie”, „naród austriacki”, „gospodarze” są przedstawiani jako winni obecnemu stanowi terenu po obozie, ale w większości przekazów pozostają bezimienni. Ich działania są przedstawiane przeważnie w stronie biernej lub wykonuje je podmiot zbiorowy. „Po wojnie baraki sprzedano, przerobiono na domy”45. „Władze austriackie pozwoliły na częściową dewastację terenu i postawienie domów mieszkalnych"46. „[Po 1955 r.] w kwestii dawnych kacetów [Austriacy] kontynuują politykę sowiecka,

zapewniające prawie 45 tys. m kw. powierzchni do produkcji kadłubów i skrzydeł myśliwców odrzutowych. Podziemne położenie sztolni chroniło przed bombardowaniami. Praca przebiegała w potwornych warunkach i przyczyniła się do śmierci tysięcy osób. Więcej w folderze „System Sztolni Begkristall": http://bewusstseinsregion.at/fileadmin/user_upload/Bergkristall/BEW_Folder_Bergkristall_web_pol.pdf (dostęp: 15 kwietnia 2018).

38 P. Bukalska, Bitwa o Gusen, „Tygodnik Powszechny”, 26 marca 2017, s. 48-51.

39 Ibidem. Wcześniej autorka artykułu, cytując historyka, pisze o pomniku ufundowanym przez więźniów, że od lat sześćdziesiątych „społeczność lokalna też zasadniczo ignorowała jego istnienie. Później się to zmieniło".

40 Ibidem.

41 J. Ćwiek, Zachować pamięć o obozie KL Gusen, „Rzeczpospolita”, 5 maja 2017 r., s. A4.

42 Depesza PAP, Magdalena Gawin: liczymy, że wtadze austriackie wykaża dobra wolę ws. obozu Gusen, data publikacji: 6 maja 2017.

43 Wiadomości TVP, wydanie główne, Przywrócić pamięć...

44 A. Skwarczyński, Przywrócić pamięć o Gusen..., s. 86-88.

45 Wiadomości TVP, wydanie główne, Przywrócić pamięć...

46 Program 1 Polskiego Radia, „Wiadomości”, data emisji: 7 maja 2017. 
a nawet posuwają się dalej w zacieraniu śladów obozu w Gusen. Cmentarz ekshumują i przenoszą do Mauthausen. Rząd zwraca właścicielowi kamieniołom, a inne tereny obozowe przekazuje gminie Gusen, które ta dzieli na działki i sprzedaje. Kacet zamienia się w schludne osiedle mieszkaniowe" ${ }^{47}$. „[Gusen] to miejsce, o które, jak mówi minister Gawin, trzeba się nadal upominać. Przez wiele lat o pamięć o Gusen dbali tylko byli więźniowie, a władze austriackie pozwoliły na częściową dewastację terenu i postawienie domów mieszkalnych na terenie miejsca zagłady tysięcy ludzi" ${ }^{48}$. Poza prezydentem Van der Bellenem rzadko pojawiają się nazwiska przedstawicieli władz austriackich. „[Wiceminister Gawin] Zaznaczyła również, że kilkukrotnie rozmawiała na temat upamiętnienia obozu w Gusen z wiceszefem austriackiego MSW Hermannem Feinerem. »Ocalając ten plac apelowy, my przede wszystkim ocalamy pamięć« - podkreśliła"49. „W niedzielnych uroczystościach uczestniczyli również prezydent Austrii Alexander van der Bellen, kanclerz Austrii Christian Kern, przedstawiciele rządu i parlamentu Austrii oraz szefowa KZ Mauthausen Memorial Barbara Glück"50.

Strona polska poprzez media kieruje apele do Austrii o zadbanie o teren po obozie: „Zróbmy wszytko, by te unikalne pozostałości ocalić i zrobić tam godne upamiętnienie" ${ }^{\text {. }}$. "Chcemy austriackie władze zmotywować do tego, że po 72 latach od zakończenia wojny przyszedł dobry czas, by zmienić swój stosunek do miejsc byłych obozów koncentracyjnych i nie uciekać od tego problemu. Nie ukrywam jednak, że stosunek do tej sprawy do tej pory był niechętny" ${ }^{\prime 2}$.

Narracja dotycząca nazw obozów odpowiada prawdzie historycznej o odpowiedzialności za II wojnę światową. Obozy koncentracyjne są nazywane „niemieckimi” lub ,niemieckimi nazistowskimi”, nie ,austriackimi”: „Likwidacja polskiej inteligencji przez niemieckich nazistów była próbą zniszczenia całego narodu, mówił wiceminister spraw zagranicznych Jan Dziedziczak"53. Podkreślana jest jednak austriacka wina za zniszczenia terenu obozu Gusen i wymazywanie go ze zbiorowej pamięci po wojnie. „Austria po wojnie przedstawiała się jako ofiara Hitlera i niechętnie eksponowała obozy koncentracyjne na swoim terytorium” "54. „[Więźniowie] przyjeżdżali [na teren KL Gusen] co roku i sami organizowali swoje uroczystości. To świadectwo niesłychanej

\footnotetext{
47 P. Bukalska, Bitwa o Gusen, „Tygodnik Powszechny”, 26 marca 2017, s. 48-51.

48 Program 1 Polskiego Radia, „Wiadomości”, data emisji: 7 maja 2017.

49 Depesza PAP, Gawin: chcielibyśmy...

50 Depesza PAP, Polska delegacja na obchodach 72. rocznicy wyzwolenia obozu Mauthausen, data publikacji: 7 maja 2017.

51 Polskie Radio 24, Dziennikarz Marek Zajac o upamiętnieniu ofiar obozu KL Gusen, data emisji: 8 maja 2017, https:/www.polskieradio.pl/80/5925/Artykul/1762342,KL-Gusen-szokujacymdowodem-na-to-jak-latwo-zatrzec-pamiec (dostęp: 15 kwietnia 2018).

52 T. Walczak, Chrońmy obóz w Gusen - to miejsce eksterminacji polskiej inteligencji, „Super Express", 6-7 maja 2017, s. 5.

53 Teleexpress TVP, W Austrii uroczystości upamiętniajace 72. rocznicę wyzwolenia obozu koncentracyjnego Mauthausen, data emisji: 8 maja 2017.

54 Polskie Radio 24, 72. rocznica wyzwolenia niemieckiego obozu zagłady Mauthausen-Gusen. Rozmowa z wiceminister kultury Magdalena Gawin, audycja „Gorący temat”, data emisji: 5 maja 2017, https://www.polskieradio.pl/130/5788/Artykul/1761445,72-lata-temu-wyzwolony-zostal-niemieckioboz-MauthausenGusen-Polacy-malo-wiedza-o-tym-obozie-zaglady (dostęp: 15 kwietnia 2018).
} 
determinacji więźniów i lekceważącego stosunku Austrii jako państwa do międzynarodowej społeczności więźniarskiej”55. „Ale choć w ostatnich 30 latach coś się zmienia, to narracja o Austrii jako »pierwszej ofierze Hitlera« jest nadal powszechna. To w tym zakrzepłym niepamiętaniu, w wysiłku, by nie spojrzeć wstecz, trzeba upatrywać przyczyn austriackiej niedbałości w opiece nad b. obozami”"56.

Wskazuje się też na większą niż innych państw - z wyjątkiem Niemiec - odpowiedzialność Austrii za zbrodnie Rzeszy Niemieckiej podczas II wojny światowej. „[wiceminister J. Dziedziczak:] Szokujące jest to, co dzieje się z tym miejscem dzisiaj. Dziwię się, że naród o bardziej skomplikowanej historii, mówiąc delikatnie, nie potrafi zachować elementarnych standardów”57. „[Magdalena Gawin:] Używamy określenia »niemiecki i nazistowski obóz koncentracyjny«, ale Austria stanowiła integralną część III Rzeszy i na pewno odpowiedzialność państwa austriackiego jest przez to dużo większa, niż w stosunku do innych podbitych narodów"58.

W przekazie polskich mediów, podobnie jak w depeszach PAP, teren, na którym niegdyś znajdował się obóz Gusen, to dziś „,śmietnik”, „teren niezabezpieczony”, „teren zdewastowany”: ,- Kiedyś nieraz płakałem, widząc, jak bardzo zdewastowany został ten teren. Dziś już jednak w pewnym sensie przyzwyczaiłem się do tego, jak nas Austriacy traktują - mówi nam Eugeniusz Śliwiński, 94-letni były więzień KL Gusen. [...] Z kolei znajdujący się za willą plac apelowy tonie dziś pod tonami śmieci i gruzu - od lat 60. na tym kawałku byłego obozu znajduje się zakład kamieniarski”59. „[Magdalena Gawin:] „Na pewno nie zrezygnujemy z tego, żeby to było prawdziwe miejsce upamiętnienia, a nie śmietnik" ${ }^{60}$., „...] Obecnie jest on w opłakanym stanie, wygląda jak gruzowisko i wysypisko śmieci” ${ }^{1}$. „Miejsce martyrologii tysięcy Polaków i osób kilkudziesięciu innych narodowości jest zaniedbane i zapomniane”62. „Jest maj 2016 r. Do środowiska byłych więźniów obozu koncentracyjnego w austriackim Gusen dobiega wieść o dewastacji dawnego placu apelowego. Plac leży w obrębie firmy kamieniarskiej, eksploatującej wciąż pobliski kamieniołom. Rozkopanie placu wzburza zwłaszcza Polaków, którzy w Gusen stanowili większość więźniów”63. „To, co ocalało, czyli krematorium, zawdzięczamy wyłącznie więźniom. Widząc nieubłaganą dewastację terenu obozu i wyrastające nowe domy, w latach 60. XX w. złożyli się i wykupili od Austrii kawałek terenu, na którym posadowione było krematorium" ${ }^{\circ 4}$.

\footnotetext{
A. Skwarczyński, Przywrócić pamięć..., s. 86-88.

Ibidem.

Wiadomości TVP, wydanie główne, Przywrócić pamięć...

58 TVP Info, audycja „Gość Poranka”, data emisji: 5 maja 2017, http://www.tvp.info/30243901/ wiceminister-kultury-o-obozie-kl-gusen-byl-ciezszy-niz-auschwitz (dostęp: 15 kwietnia 2018).

59 P. Włoczyk, Austria wciaż obojętna wobec śmietnika na terenie KL Gusen, data publikacji: 15 maja 2017, https://dorzeczy.pl/historia/29515/Austria-wciaz-obojetna-wobec-smietnika-na-terenie-KL-Gusen.html (dostęp: 15 kwietnia 2018).

${ }^{60} \quad$ Wiadomości TVP, wydanie główne, Przywrócić pamięć...

61 A. Skwarczyński, Przywrócić pamięć o Gusen..., s. 86-88.

62 P. Falkowski, Kruszenie niepamięci, „Nasz Dziennik”, 9 maja 2017, s. 1.

63 P. Bukalska, Bitwa o Gusen..., s. 48-51.

64 A. Skwarczyński, Przywrócić pamięć o Gusen..., s. 86-88.
} 
Działania Polski pokazane są w kontrze do destrukcyjnych działań Austrii względem terenów poobozowych. Polska - ,upamiętnienia”, ,zapobiega dewastacji”, „przywraca pamięć”, „zabiega o dialog”. „Dzięki staraniom polskiego MSW, MSZ i Ministerstwa Kultury udało się objąc ochroną konserwatora zabytków plac apelowy w Gusen. Dziś jest tu zakład kamieniarski. Austriackie władze muszą wykupić teren”65. „Polski rząd stara się przekonać Wiedeń do odkupienia placu apelowego i przywrócenia mu pierwotnego wyglądu”66. „Polska od kilku miesięcy zabiega u władz Austrii o zaprzestanie dewastacji tego miejsca, a także upamiętnienie zamordowanej tam polskiej inteligencji" ${ }^{67}$. „Liczymy na to, że władze austriackie będą chciały z nami podjąć dialog; dotychczasowe rozmowy są w zasadzie jednostronne" ${ }^{68}$. „[...] udało się dzięki działaniom strony polskiej objąć były plac apelowy obozu w Gusen ochroną konserwatorską, to jest bardzo duży sukces strony polskiej" ${ }^{69}$.

Bardzo niewiele jest informacji o pozytywnych działaniach władz Austrii. „,Trzeba powiedzieć o takich przedsięwzięciach, jak projekt dokumentacyjno-badawczy »Mauthausen Survivors Documentation Project«, w ramach którego w latach 2002-03 badacze z niemal 30 krajów nagrali ok. 850 wywiadów z więźniami systemu Mauthausen. Finansowało go austriackie MSW"70. „Pytanie] A jak wyglądają rozmowy z władzami austriackimi? [odpowiedź wiceminister Gawin] Odnotowaliśmy postęp w postaci tego, że władze austriackie zdecydowały się na założenie rejestru dla placu obozowego, co zabezpiecza go o tyle, że nie powstanie tam osiedle mieszkaniowe, które miało zostać tam wybudowane" niarska. Późną jesienią teren trafił do rejestru zabytków i tutaj służby konserwatorskie zadziałały poprawnie" ${ }^{72}$.

Spośród programów informacyjnych, wzmianki o konferencji „Zabijanie inteligencji. Europejskie elity intelektualne pod okupacją niemiecka, 1939-1945" pojawiały się w materiałach Wiadomości TVP, Tok FM, Teleexpressu i Programu I PR ${ }^{73}$. „Konieczna jest ochrona tego, co pozostało z obozu, ale i dyskusja o tym, jak łatwo można zapomnieć o tragedii. Dlatego Instytut Polski wraz z Ośrodkiem Badań nad Totalitaryzmami

\footnotetext{
65 Wiadomości TVP, wydanie główne, Przywrócić pamięć...

${ }^{66}$ P. Włoczyk, Austria wciqż obojętna..., https://dorzeczy.pl/historia/29515/Austria-wciaz-obojetna-wobec-smietnika-na-terenie-KL-Gusen.html (dostęp: 15 kwietnia 2018).

67 J. Ćwiek, Zachować pamięć..., s. A4.

68 Depesza PAP, Wiceminister Gawin o stanowisku austriackiego MSW ws. upamiętnienia obozu $w$ Gusen, data publikacji: 8 maja 2017.

69 Instytut Polski $w$ Wiedniu promuje polska kulturę i sztukę. Dba również o upamiętnienie miejsc zagłady Polaków z II WŚ, data publikacji: 12 maja 2017, http://wnet.fm/2017/05/12/instytut-polski-wiedniu-promuje-polska-kulture-sztuke-dba-rowniez-o-upamietnienie-miejsc-zaglady-polakow-ii-ws (dostęp: 15 kwietnia 2018).

70 P. Bukalska, Bitwa..., s. 48-51.

71 T. Walczak, Chrońmy obóz..., s. 5.

72 A. Skwarczyński, Przywrócić pamięć o Gusen..., s. 86-88.

73 O uroczystościach w Austrii, w szczególności o przebiegu konferencji „Zabijanie inteligencji. Europejskie elity intelektualne pod okupacją niemiecka, 1939-1945", informował też na swojej stronie internetowej Ośrodek Badań nad Totalitaryzmami im. Witolda Pileckiego, https://obnt.pl/ pl/aktualnosci/konferencja-gusenwieden (dostęp: 15 kwietnia 2018).
} 
im. Witolda Pileckiego rozpoczął dziś w Wiedniu międzynarodową konferencje naukową" 74 . „Wiceministrowie otworzą międzynarodową konferencję zatytułowaną »Killing Intellectuals. European Intellectual Elites Under German Occupation«. Taki tytuł piękny. Konferencja została zorganizowana przez Instytut Polski w Wiedniu i Ośrodek Badań nad Totalitaryzmami przy współpracy MSZ oraz MKiDN”75. „Likwidacja polskiej inteligencji przez niemieckich nazistów była próbą zniszczenia całego narodu, mówił wiceminister spraw zagranicznych Jan Dziedziczak. Otworzył on konferencję poświęco-

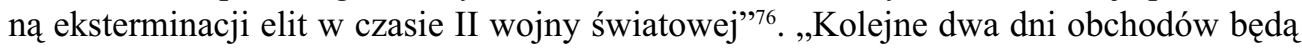
poświęcone na konferencję naukową"77. W prasie napisał o niej m.in. „Nasz Dziennik”: „Wczoraj w Wiedniu odbyła się konferencja na ten temat zorganizowana przez działający przy resorcie Ośrodek Badań nad Totalitaryzmami im. Witolda Pileckiego"78.

W niewielu mediach występuje informacja o roli Amerykanów w wyzwoleniu obozu: „72 lata temu Amerykanie wyzwolili niemieckie obozy koncentracyjne Mauthausen-Gusen. To jedno z miejsc, gdzie Niemcy prowadzili zaplanowaną zagładę polskiej inteligencji"’79. „72 lata temu wojska amerykańskie wyzwoliły niemiecki nazistowski obóz Mauthuasen-

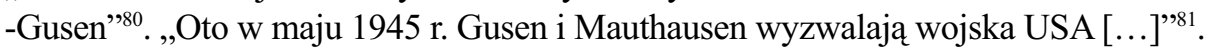

Wyjaśnienie roli Sowietów w planowym niszczeniu obozu w okresie okupacji Austrii, które stanowi okoliczność łagodzącą odpowiedzialność Austrii za zniszczenia, znajduje się jedynie w „Tygodniku Powszechnym”. „Odpowiedź na pytanie, dlaczego Gusen nie był potem upamiętniany, kryje się nie w administracyjnych zawiłościach III Rzeszy, lecz w tym, co stało się w Austrii po wojnie. [...] kontrolę nad terenem szybko przejmują Sowieci - Austria, jak Niemcy, zostaje podzielona na strefy okupacyjne. W $1947 \mathrm{r}$. dawny obóz w Mauthausen zostaje wybrany jako miejsce upamiętnienia i przekazany władzom austriackim, a teren Gusen dalej nadzorują Sowieci. [...] Gusen, gdzie ginęła polska inteligencja, a także sowieccy jeńcy, jest Moskwie bardzo nie na rękę ${ }^{82}$.

Choć w mediach przede wszystkim nacisk kładzie się na podkreślanie wyjątkowości polskiego aspektu obozu Gusen, to w cytowanych wypowiedziach pojawiają się też wątki przypominające o jego międzynarodowym charakterze. „[Byli więźniowie KL Gusen] przyjeżdżali tam co roku i sami organizowali swoje uroczystości. To świadectwo niesły-

\footnotetext{
74 Wiadomości TVP, wydanie główne, Przywrócić pamięć...

75 Tok FM, „Pierwsze Śniadanie w TOK-u”, data emisji: 8 maja 2017.

76 Teleexpress TVP, W Austrii uroczystości upamiętniajace 72. rocznicę wyzwolenia obozu koncentracyjnego Mauthausen, data emisji: 8 maja 2017.

77 Program 1 Polskiego Radia, „Wiadomości”, data emisji: 7 maja 2017.

78 P. Falkowski, Kruszenie niepamięci, s. 1.

79 Wiadomości TVP, wydanie główne, Przywrócić pamięć...

80 Program 1 Polskiego Radia, „Wiadomości”, data emisji: 7 maja 2017.

81 P. Bukalska, Bitwa..., s. 48-51.

82 Ibidem. W rzeczywistości niszczenie terenu poobozowego zaczęło się już w trakcie krótkiej obecności Amerykanów, np. w połowie maja 1945 roku budynki i drewniane baraki Gusen II spalono z powodu plagi robactwa i groźby epidemii. Sowieci dokonali grabieży i wywózki mienia oraz eksploatowali kamieniołomy. Ich oficerowie polityczni zadbali o to, by zatrzeć ślady obozu, aby nic nie przypominało o tym, że radzieccy żołnierze dostawali się do niewoli. Upamiętnienie ofiar innych narodowości nie było dla nich istotne. Po 1955 roku tereny po obozie zostały sprzedane prywatnym właścicielom.
} 
chanej determinacji więźniów i lekceważącego stosunku Austrii jako państwa do międzynarodowej społeczności więźniarskiej”83, „Gusen samo w sobie jest pomnikiem tragicznych dziejów Europy, a tym samym pamięć o dawnym obozie stanowi istotny element dziedzictwa Starego Kontynentu. Dlatego konieczna jest nie tylko ochrona materialnych pozostałości, lecz także systematyczna i pogłębiona refleksja nad mechanizmami pamięci - przede wszystkim nad łatwością zapominania o tragedii, która ukształtowała współczesną Europę - powiedział Marek Zając, sekretarz Międzynarodowej Rady Oświęcimskiej i przewodniczący Rady Fundacji Auschwitz-Birkenau”84. „Mam nadzieję, że tak [że Austriacy zapoznają się z polską koncepcją upamiętnienia obozu Gusen]. Będzie przedstawiana w Wiedniu dwukrotnie na międzynarodowej konferencji, która przygotował Ośrodek Badań nad Totalitaryzmami im. Witolda Pileckiego, oraz na spotkaniu z dyplomatami. O postępach w rozmowach z austriackim MSW będziemy informować opinię publiczną w Polsce i za granica. W końcu KL Gusen to miejsce o międzynarodowym charakterze” ${ }^{\text {. }}$, Wiceminister zaznaczyła, że obóz KL Gusen to miejsce międzynarodowe i szczególnie ważne dla Polski. »Wydaje mi się, że przede wszystkim udało nam się przekonać tę lokalną społeczność, że mówiąc na temat inteligencji polskiej, my nie wyrażamy swojego nacjonalizmu, tylko tak naprawdę mówimy o elitach europejskich, o ludziach bardzo zasłużonych dla kultury polskiej i dla Europy« - powiedziała wiceminister kultury" $"$.

\section{Przekaz w mediach austriackich}

Główne media informowały, że obchody w Mauthausen toczą się pod hasłem „Wielonarodowość łączy". W relacjach i artykułach prasowych pojawiały się nawiązania do sytuacji w Unii Europejskiej - rosnącego nacjonalizmu i kryzysu uchodźczego, a Mauthausen przedstawiano jako przestrogę, że nacjonalizm, ksenofobia i rasizm przynoszą zgubne skutki. W kontekście uroczystości zacytowano przewodniczącego Komitetu Mauthausen, Williego Mernyiego: „Ponadnarodowość jest najważniejszą myślą przewodnią" ${ }^{87}$. Podkreślano zaangażowanie młodych Austriaków w obchody rocznicy wyzwolenia obozu. Pojawiły się też informacje o tym, że obóz wyzwolili Amerykanie, oraz o czarnoskórych więźniach Mauthausen ${ }^{88}$.

Sam obóz Gusen występował w następujących kontekstach, związanych pośrednio lub bezpośrednio z Polską: Gusen jako miejsce niewolniczej pracy na rzecz niemieckiego systemu zbrojeniowego w okresie II wojny światowej; zarzuty polskiego rządu o braku dobrej woli ze strony Austrii, by wykupić teren byłego obozu; Polska jako kraj

\footnotetext{
83 A. Skwarczyński, Przywrócić pamięć o Gusen..., s. 86-88.

84 Dziś rocznica wyzwolenia bylego NIEMIECKIEGO obozy zagłady...

85 A. Skwarczyński, Przywrócić pamięć o Gusen..., s. 86-88.

86 Depesza PAP, Austria/ Dziedziczak: przez likwidację polskiej elity miat być zniszczony naród, data publikacji: 8 maja 2017.

877.000 gedenken in Mauthausen, data publikacji: 7 maja 2017, https://derstandard.at/ 2000057128433/7-000-gedenken-in-Mauthausen (dostęp: 15 kwietnia 2018).

88 I. Brickner, Afrikaner im KZ Mauthausen: ,Anklang an Hofmohrentradition und Sklaverei“, data publikacji: 7 kwietnia 2017, https://derstandard.at/2000055381565/Afrikaner-im-KZ-Mauthausen-Anklang-an-Hofmohrentradition-und-Sklaverei (dostęp: 15 kwietnia 2018).
} 
przeszkadzający w godnym upamiętnieniu rocznicy wyzwolenia obozu; chęć powołania przez Polskę centrum edukacji i wymiany młodzieży na terenie Gusen; Austria odrzucająca polską krytykę; obawy Austrii, że czczenie polskich bohaterów może przysłonić szczere upamiętnianie ofiar obozów.

Gusen pojawiło się też w dwóch kontekstach niezwiązanych z Polską: w informacji o przygotowaniach do pierwszego sympozjum o prawach człowieka w ramach Regionu Świadomości Mauthausen-Gusen-St.Georgen ${ }^{89}$ oraz w mediach lokalnych i katolickich o przygotowaniach przedstawienia teatralnego w Linzu na temat życia „Papy Grubera” - księdza katolickiego, uznawanego za najbardziej znanego działacza austriackiego ruchu oporu, który zginął w Gusen ${ }^{90}$.

\begin{tabular}{|l|l|}
\hline \multicolumn{2}{|c|}{$\begin{array}{c}\text { Artykuły nt. Gusen w kontekście obchodów 72. rocznicy wyzwolenia obozu, } \\
\text { w austriackiej prasie i internecie }\end{array}$} \\
\hline $\begin{array}{l}\text { „Oberösterreichische Nachrichten”, } \\
25 \text { kwietnia } 2017\end{array}$ & $\begin{array}{l}\text { „Bevölkerung um Mauthausen soll bei } \\
\text { Befreiungsfeier mehr Präsenz zeigen”, B. Leitner }\end{array}$ \\
\hline $\begin{array}{l}\text { strona „Salzburger Nachrichten“ sn.at, } \\
6 \text { maja } 2017\end{array}$ & $\begin{array}{l}\text { „Polen: Österreich behindert Gedenken } \\
\text { an ehemaliges KZ Gusen” (depesza APA) }\end{array}$ \\
\hline $\begin{array}{l}\text { strona „Der Standard” DerStandard.at, } \\
7 \text { maja } 2017\end{array}$ & $\begin{array}{l}\text { „Österreich weist Kritik Polens zu KZ- } \\
\text {-Gedenkstätte Gusen zurück” (depesza APA) }\end{array}$ \\
\hline $\begin{array}{l}\text { strona „Die Presse” DiePresse.com, } \\
7 \text { maja } 2017\end{array}$ & $\begin{array}{l}\text { „Van der Bellen: Nationalismus löst keine } \\
\text { Probleme”, G. Bitzan }\end{array}$ \\
\hline strona „Heute” heute.at, 7 maja 2017 & „Verstimmung rund um Mauthausen-Gedenken” \\
\hline strona „Tips” tips.at, 7 maja 2017 & $\begin{array}{l}\text { „Bundespräsident warnt vor Ausgrenzung } \\
\text { Anderer”, M. Frühwirth }\end{array}$ \\
\hline „Die Presse”, 8 maja 2017 & „Nationalismus löst keine Probleme”, G. Bitzan \\
\hline Dioezese-linz.at, 8 maja 2017 & $\begin{array}{l}\text { „Gedenken in Gusen: „Man muss in allen } \\
\text { Lebenslagen Mensch bleiben”, M. Weilguni, } \\
\text { B. Mühleder }\end{array}$ \\
\hline
\end{tabular}

89 E. Glück, Menschenrechte nachhaltig in der Region verankern, data publikacji: 27 czerwca 2017, https://www1.meinbezirk.at/perg/c-lokales/menschenrechte-nachhaltig-in-der-region-verankern_a2169048 (dostęp: 15 kwietnia 2018). Artykuł ukazał się też drukiem w gazecie „Bezirks -Rundschau Perg”, 10 maja 2017, s. 2. „Region Świadomości Mauthausen-Gusen-St.Georgen” to powołany w 2016 roku związek gminny, w skład którego wchodzą samorządowcy, przedstawiciele organizacji pozarządowych i mieszkańcy gminy Langenstein, na terenie której są zlokalizowane pozostałości KL Gusen. Projekt „Region Świadomości Mauthausen - Gusen - St. Georgen” wychodzi naprzeciw pragnieniu obchodzenia się z historią obciążoną negatywnymi zdarzeniami, w sposób zorientowany na przyszłość. Twórcy projektu uważają że stworzenie nowych form politycznego uczestnictwa i edukacji społeczno-politycznej umożliwi mieszkańcom regionu świadome związanie się z nim bez konieczności dystansowania się od negatywnych faktów historycznych. Koncepcja ma na celu zniesienie podziału między przeszłością i przyszłością. Więcej o inicjatywie: www.bewusstseinsregion.at.

90 M. Frühwirth, Der Fall Gruber: nach Uraufführung startet Tournee, data publikacji: 26 czerwca 2017, https://www.tips.at/news/st-georgen-an-der-gusen/kultur/396176-der-fall-gruber-nachurauffuehrung-startet-tournee (dostęp: 15 kwietnia 2018). 


\begin{tabular}{|c|c|}
\hline $\begin{array}{l}\text { strona „Der Standard” DerStandard.at, } \\
8 \text { maja } 2017\end{array}$ & $\begin{array}{l}\text { „Polnische Kritik: Gedenkstätten-Leiterin } \\
\text { sieht »politische Strategie«”, M. Rohrhofer } \\
\text { (rozmowa z B. Glück) }\end{array}$ \\
\hline „Der Standard”, 8 maja 2017 & $\begin{array}{l}\text { „Mauthausen Gedenken: Kritik aus Polen; } \\
\text { Osterreich »behinderte« Gedenkarbeit”, (mro) }\end{array}$ \\
\hline „Der Standard”, 8 maja 2017 & $\begin{array}{l}\text { „Die Hölle vor der Haustüre. Doku-Reihe zu } \\
\text { Mauthausen auf ORF 3” (zapowiedź programu } \\
\text { telewizyjnego), C. M. Schmidt }\end{array}$ \\
\hline „Wiener Zeitung”, 8 maja 2017 & $\begin{array}{l}\text { „Gedenken an Befreiung des KZ Mauthausen”, } \\
\text { P. Lechner }\end{array}$ \\
\hline $\begin{array}{l}\text { strona „Oberösterreichische Nachrich- } \\
\text { ten” Nachrichten.at, } 8 \text { maja } 2017\end{array}$ & $\begin{array}{l}\text { „Freiheit des Menschen als höchstes Gut”, } \\
\text { B. Leitner }\end{array}$ \\
\hline $\begin{array}{l}\text { „Oberösterreichische Nachrichten”, } \\
8 \text { maja } 2017\end{array}$ & $\begin{array}{l}\text { „Festakt in KZ-Gedenkstätte Mauthausen. Frei- } \\
\text { heit des Menschen als höchstes Gut”, B. Leitner }\end{array}$ \\
\hline $\begin{array}{l}\text { strona „Oberösterreichische Nachrich- } \\
\text { ten” Nachrichten.at, } 9 \text { maja } 2017\end{array}$ & $\begin{array}{l}\text { „Polen verstärkt den Druck für Ausbau der KZ- } \\
\text {-Gedenkstätte”, B. Leitner }\end{array}$ \\
\hline $\begin{array}{l}\text { „Oberösterreichische Nachrichten } \\
\text { Mühlviertler Nachrichten”, } 9 \text { maja } 2017\end{array}$ & $\begin{array}{l}\text { „Polen verstärkt den Druck für einen Ausbau } \\
\text { der KZ-Gedenkstätte Gusen”, B. Leitner }\end{array}$ \\
\hline $\begin{array}{l}\text { „Oberösterreichische Nachrichten”, } \\
9 \text { maja } 2017\end{array}$ & „Aufwertung” (komentarz odredakcyjny) \\
\hline „Perger Tips”, 10 maja 2017 & $\begin{array}{l}\text { „Bundespräsident warnt vor der Ausgrenzung } \\
\text { Anderer” }\end{array}$ \\
\hline „Die Presse”, 11 maja 2017 & $\begin{array}{l}\text { „Neue Pläne für Umgestaltung des KZ Gusen”, } \\
\text { G. Bitzan }\end{array}$ \\
\hline $\begin{array}{l}\text { strona „Der Standard” DerStandard.at, } \\
11 \text { maja } 2017\end{array}$ & $\begin{array}{l}\text { „Gemeinsame Pläne für Gedenkstätte Gusen } \\
\text { - und Kritik”, (bri) }\end{array}$ \\
\hline „Der Standard”, 12 maja 2017 & „Pläne für Gedenkstätte Gusen: Kritik”, (bri) \\
\hline „Profil” nr 20/2017, 15 maja 2017 & „Polnische Intervention”, (ol) \\
\hline „Wiener Zeitung”, 26 maja 2017 & $\begin{array}{l}\text { „Österreich schafft Hoffnung und Internationa- } \\
\text { lität in Europa”, A. Casals (list do redakcji) }\end{array}$ \\
\hline
\end{tabular}

a Depesza przywoływana również przez portale innych gazet, m.in.: Kleine Zeitung, Österreich i ORF (http://www.kleinezeitung.at/politik/innenpolitik/5213483/Konzentrationslager_MauthausenGedenken_Appell-an-Respekt-vor-dem, http://www.oe24.at/oesterreich/chronik/Oesterreich-soll-Gedenkenan-ehemaliges-KZ-verhindern/281490978, http://orf.at/stories/2390362). Pozostałe wymienione depesze APA również pojawiały się na innych portalach.

Cytowane w mediach wypowiedzi przedstawicieli władz Austrii na temat Gusen są powiązane $\mathrm{z}$ bieżącą sytuacją polityczną $\mathrm{w}$ Polsce, $\mathrm{w}$ tym m.in. $\mathrm{z}$ dialogiem KE z polskimi władzami w kontekście ram na rzecz praworządności oraz ogólnej zmiany akcentów w polskiej polityce historycznej na bardziej polonocentryczne, jak dekomunizacja nazw ulic, reforma programów nauczania historii w szkołach, nowe listy lektur czy zmiany ekspozycji w muzeach. Barbara Glück, szefowa Urzędu Federalnego „Memoriał Mauthausen”, w „Der Standard” mówi: „To oczywiste, że PiS realizuje poli- 
tyczną strategię, która ma służyć wyłącznie pisaniu polsko-nacjonalistycznej historii"’1. W innym artykule „Der Standard” przywołuje jej wypowiedź: „W dbaniu o największy niemiecki obóz koncentracyjny w Austrii nie chodzi o polityczną strategię PiS, lecz o zrealizowanie woli byłych więźniów i ekspertów"92.

O polsko-austriackim sporze międzyrządowym wokół KL Gusen donosiły przede wszystkim depesze APA, cytowane przez portale informacyjne, ale również prasa. „Mühlviertler Nachrichten”, lokalne wydanie „OÖNachrichten”, pisało, iż po krytycznych słowach Magdaleny Gawin na temat braku zaangażowania Austrii w wysiłki na rzecz upamiętnienia KL Gusen, „rzecznik austriackiego MSW Karl-Heinz Grundböck ocenił, że moment krytyki przeczy »duchowi wspólnoty w myśleniu«. Po krótkim oburzeniu wypowiedziami Gawin w niedzielę, już w niedzielę wieczorem doszło do rozmów wyjaśniających z przedstawicielami obu państw i przewodniczącym Międzynarodowego Komitetu Mauthausen, Guy'em Dockendorfem z Luksemburga. »Przy tej okazji niektóre sprawy zostały usunięte. Porozumiano się co do tego, że zarówno Polska jak i Austria chcą wzmocnienia pracy ku czci pamięci« - powiedział [redakcji] jeden z uczestników [spotkania] [...]"'93.

Spośród mediów austriackich jedynie w „Tips”, w „OÖ Nachrichten” i na stronie internetowej diecezji w Linzu można było odnaleźć informację o wizycie prezydenta Austrii przy Memoriale KL Gusen. W drukowanym wydaniu „Perger Tips” zamieszczono zdjęcie prezydenta Austrii z podpisem „Alexander Van der Bellen jako pierwszy prezydent odwiedził miejsce pamięci KL Gusen” 94 . W artykule w „OÖ Nachrichten” znalazło się zdjęcie i cytat z przemówienia prezydenta, pojawiło się również zdanie: „Już w sobotę upamiętniono ofiary obozów koncentracyjnych w Ebensee, Spital am Pyhrn, Gunskirchen i Gusen. [...] W Gusen Alexander Van der Bellen był pierwszą urzędującą głową państwa, która wzięła udział w uroczystościach"95. Wyłącznie na stronie diecezji linckiej podano temat przewodni uroczystości rocznicowych wyzwolenia obozu KL Gusen - „Prawa człowieka są niepodzielne”"96.

91 M. Rohrhofer, Gebt uns die Chance, etwas zu entwickeln, „Der Standard”, 9 maja 2017, s. 8, https://derstandard.at/2000057190451/Polnische-Kritik-Gedenkstaetten-Leiterin-sieht-politischeStrategie (dostęp: 15 kwietnia 2018).

92 Gemeinsame Pläne für Gedenkstätte Gusen - und Kritik, ,Der Standard”, 12 maja 2017, s. 10, https://derstandard.at/2000057396195/Gemeinsame-Plaene-fuer-Gedenkstaette-Gusen-und-Kritik (dostęp: 15 kwietnia 2018).

93 B. Leitner, Polen verstärkt den Druck für einen Ausbau der KZ-Gedenkstätte Gusen, „OÖ Nachrichten - Mühlviertler Nachrichten", 9 maja 2017, s. 1, http://www.nachrichten.at/oberoesterreich/muehlviertel/Polen-verstaerkt-den-Druck-fuer-Ausbau-der-KZ-Gedenkstaette;art69,256 0591 (dostęp online: 15 kwietnia 2018).

94 „Tips” to darmowa, regionalna gazeta austriacka, ukazująca się w dwóch krajach związkowych (Górnej i Dolnej Austrii). Istnieje od 1986 roku, posiada 31 mutacji prasowych. Jedna z nich, „Perger Tips", ukazuje się w powiecie Perg w Górnej Austrii, na terenie którego znajduje się gmina St. Georgen an der Gusen.

95 B. Leitner, Festakt in KZ-Gedenkstätte Mauthausen. Freiheit des Menschen als höchstes Gut, 8 maja 2017, „OÖ Nachrichten”, s. 20, http://www.nachrichten.at/oberoesterreich/Freiheit-desMenschen-als-hoechstes-Gut;art4,2560316 (dostęp online: 15 kwietnia 2018).

96 M. Weilguni, B. Mühleder, Gedenken in Gusen: „,Man muss in allen Lebenslagen Mensch bleiben", data publikacji: 8 maja 2017, https://www.dioezese-linz.at/news/2017/05/08/gedenken- 
W artykule zapowiadającym wydarzenia rocznicowe przy Memoriale Gusen przedstawiciel władz lokalnych wspomina w koncyliacyjnym tonie o spotkaniu młodzieży z Austrii, Włoch i Polski, które miało miejsce 5 maja przy wejściu do sztolni „Bergkristall”. „To właśnie młodym udaje się bardzo szybko pokonać różnice językowe i kulturowe i razem coś poruszyć" - mówi burmistrz St. Georgen, Erich Wahl"97.

Podkreślano, że Austrii oraz innym państwom, których obywatele zginęli w KL Gusen, nie podoba się to, że Polska chce zdominować pamięć o obozie i upamiętniać na jego terenie wyłącznie polskie ofiary. „Rząd w Warszawie zarzuca Austrii, że za mało angażuje się na rzecz upamiętnienia polskich ofiar. Polski rząd i związki ofiar chcą teraz same zrobić więcej. Nie zawsze podoba się to innym krajom, które mają obawę, że zostaną zdyskredytowane przez Warszawę" ${ }^{98}$. Możliwym rozwiązaniem byłoby ustanowienie centrum edukacyjnego im. Sławika. Na temat chęci powołania przez Polskę europejskiego miejsca pamięci, które upamiętniałoby nie tylko polskie ofiary KL Gusen i tym samym było akceptowalne przez Austrię i inne państwa, napisano m.in. w artykule w „Die Presse”, konkludując, że ,z nowym pomysłem e u ro pej s ki e g o m i ej s c a p a m i ę c i [wyróż. A.P.] prawdopodobnie wszyscy mogliby się zgodzić" 99 .

Niezwykle trafnie spór polsko-austriacki wokół Gusen opisano we „wstępniaku” do „Oberösterreichische Nachrichten”: „Odpowiedzialność za wypełnienie obowiązku pamięci o ofiarach maszynerii śmierci obozów koncentracyjnych skupia się w Austrii przede wszystkim na Mauthausen. To tu mają miejsce międzynarodowe obchody wyzwolenia, jak również większość naukowych i pedagogicznych projektów dotyczących pracy z historycznymi wydarzeniami. To, że „podobóz” Gusen znajduje się w cieniu Mauthausen, chociaż tu mieścił się większy kompleks [obozowy], wydaje się niektórym niepoparte stosowną argumentacją. Lokalne inicjatywy starają się - tak samo jak Polska, która w KL Gusen widzi symbol systematycznego wyniszczania polskiej inteligencji - nadać [Gusen] odpowiednią rangę w dyskursie publicznym. Byłoby zupełnie niewłaściwe, by uruchomić w tej sprawie rywalizację, który z tutejszych obozów koncentracyjnych był okrutniejszy. Jest również faktem, że obszar [obozu] krótko po zakończeniu wojny został przekazany pod prywatną zabudowę, i stąd możliwości dla miejsca pamięci są ograniczone. Nadanie [terenowi byłego obozu Gusen] odpowiedniej rangi jest przyjmowane z zadowoleniem. Kroki ku temu powinny jednak być stawiane ostrożnie i na bazie konsensusu" 100 .

in-gusen-man-muss-in-allen-lebenslagen-mensch-bleiben (dostęp: 15 kwietnia 2018). Poza tym informacja w języku niemieckim o wizycie prezydenta Austrii przy Memoriale Gusen znalazła się na stronie lokalnej partii SPÖ (https://langenstein.spooe.at/2017/05/13/befreiungsfeier-im-memorial-gusen) oraz na stronie Memoriału Mauthausen (https://www.mauthausen-memorial.org/de/ Aktuell/Rueckblick-auf-die-Gedenk-und-Befreiungsfeiern-2017).

97 B. Leitner, Bevölkerung um Mauthausen soll bei Befreiungsfeier mehr Präsenz zeige, „Oberösterreichische Nachrichten”, 25 kwietnia 2017.

98 G. Bitzan, Nationalismus löst keine Probleme, „Die Presse”, 8 maja 2017, s. 5, https://diepresse.com/home/innenpolitik/5213669/Van-der-Bellen_Nationalismus-loest-keine-Probleme (dostęp: 15 kwietnia 2018).

99 G. Bitzan, Neue Pläne für Umgestaltung des KZ Gusen, „Die Presse”, 11 maja 2017, s. 12.

100

Aufwertung, „Oberösterreichische Nachrichten”, 8 maja 2017, s. 1. 
W przeciwieństwie do analogicznego okresu w latach poprzednich, nie znalazłam $\mathrm{w}$ informacyjnej audycji radiowej lub telewizyjnej (w wiadomościach: Zeit im Bild ORF, Aktuell ATV, PULS 4 News Puls4/ProSieben/Sat1 czy lokalnych wiadomościach Oberösterreich heute ORF Oberösterreich) materiału o obchodach wyzwolenia Mauthausen-Gusen ${ }^{101}$. W telewizji i radiu ORF była mowa o obchodach święta 8 maja, czyli Dnia Pamięci przeciwko Przemocy i Rasizmowi (upamiętniającego ofiary nazizmu i wyzwolenie spod władzy nazistowskiej). W 2017 roku dzień ten przebiegał pod hasłem „Święta radości”. W telewizji pokazano na żywo uroczyste posiedzenie obu izb parlamentu oraz „koncert pokoju” w wykonaniu Wiedeńskiej Orkiestry Symfonicznej. Poza serią filmów o Mauthausen, publiczny kanał ORF wyemitował 5 maja o godz. 23.30 rozmowę z austriackim Żydem, Abą Lewitem, który przeżył Mauthausen ${ }^{102}$.

6 maja 2017 roku o godz. 20.15 austriacki nadawca państwowy ORF III nadał jeden z odcinków serii trzech filmów dokumentalnych „Przed drzwiami Mauthausen” - Praca przymusowa dla zbrojeń i przemyslu. Część dokumentu, od ok. 11. do 15. minuty $\mathrm{z}$ blisko 47 minut całego filmu, jest poświęcona Gusen, który został przedstawiony jako obóz potrzebny przede wszystkim niemieckiemu przemysłowi podczas II wojny światowej. Historyk z Uniwersytetu Wiedeńskiego, prof. Bertrand Perz, informuje, że Gusen było dużym obozem, ale podporządkowanym Mauthausen. Następnie pojawiają się wspomnienia pracownika kamieniołomów, Franza Hackla, który pracował z więźniami jako ,praktykant” $i$ widział ich cierpienie. W jednym z ostatnich kadrów filmu jest pokazana bez komentarza brama do prywatnego domu, która niegdyś była bramą wjazdową do obozu Gusen. Narrator mówi: „Fragmenty podobozów istnieją ale w części są zamazane. W miejscach, gdzie wcześniej stały obozy koncentracyjne, dziś stoją osiedla". Informacja o polskich ofiarach Gusen ani o wyjątkowości tego „podobozu” na tle całego systemu obozów podlegających Mauthausen nie pojawia się w dokumencie.

Na stronie Ministerstwa Spraw Wewnętrznych Austrii, które finansuje miejsca pamięci z okresu II wojny światowej na terenie Austrii, brak jest aktualnej lub jakiejkolwiek wzmianki o obozie Gusen. Jest tylko krótki artykuł o Memoriale Mauthau$\operatorname{sen}^{103}$. W magazynie wydawanym przez austriackie Ministerstwo Spraw Wewnętrznych „Öffentliche Sicherheit” Gusen w badanym okresie się nie pojawia. W historii wydawania

101 Np. ORF Burgenland, audycja Servus Szia Zdravo Del'tuha, Gedenkfeier in Mauthausen, data emisji 8 czerwca 2014, http://tvthek.orf.at/profile/Archiv/7648449/Gedenkfeier-in-Mauthausen/8949048/Gedenkfeier-in-Mauthausen/8949049; ORF 2, wiadomości Zeit im Bild, Befreiungsfeier in Mauthausen, data emisji: 8 maja 2011, http://tvthek.orf.at/profile/Archiv/7648449/Befreiungsfeier-in-Mauthausen/9509544/Befreiungsfeier-in-Mauthausen/9509545; ORF Oberösterreich, wiadomości Oberösterreich heute, Gegen das Vergessen: Gedenkfeier in Mauthausen, data emisji: 10 maja 2009, http://tvthek.orf.at/profile/Archiv/7648449/Gegen-das-Vergessen-Gedenkfeier-inMauthausen/12606446/Gegen-das-Vergessen-Gedenkfeier-in-Mauthausen/12606447; Radio Oberösterreich, audycja „Schwerpunkt oö. Zeitgeschichte”, data emisji: 3 maja 2015, http://ooe.orf. at/radio/stories/2708346 (dostęp: 15 kwietnia 2018).

102 ORF eins, audycja ZIB-24, Aba Lewit: ,, Seelisch knabbert es”, data emisji: 5 maja 2017, http:// tvthek.orf.at/topic/Gedenken-an-die-Befreiung-vom-Nationalsozialismus/13869230/Aba-LewitSeelisch-knabbert-es/13929048 (dostęp: 15 kwietnia 2018).

103 Mauthausen Memorial | KZ-Gedenkstätte, http://www.bmi.gv.at/404/start.aspx (dostęp: 15 kwietnia 2018). 
magazynu występuje dwa razy, tylko na marginesie okragłych rocznic wyzwalania obozu Mauthausen. Nie ma wzmianki o polskim kontekście obozu lub o polskich ofiarach. W numerze 3-4/2005 bohaterem artykułu z 2005 roku jest weteran amerykański, który wyzwalał Mauthausen. W tekście jest wymieniona liczba osób biorących udział w obchodach wyzwolenia KL Gusen ${ }^{104}$. Z kolei w artykule w numerze 7-8 z roku 2015 opisano losy więźnia Mauthausen - austriackiego Roma. Na końcu artykułu jest ramka z jednym zdaniem o udziale ministra spraw wewnętrznych w obchodach przy Memoriale Gusen ${ }^{105}$.

Analizując media austriackie, doniesienia o obchodach wyzwolenia obozu Mauthausen odnalazłam jedynie w mediach drukowanych i internetowych. Inaczej niż w przypadku mediów polskich, żaden materiał nie dotyczył wyłącznie uroczystości pod Memoriałem KL Gusen lub organizowanych przez stronę polską konferencji, koncertu czy spotkań dla byłych więźniów i młodzieży ${ }^{106}$.

Ogólnie w mediach austriackich na temat Polski w badanym okresie mówiło się wyłącznie w negatywnym kontekście i tonie. Doniesienia z Polski dotyczyły takich tematów jak: niechęć Polski do przyjmowania uchodźców, krytyka Niemiec ze strony Polski za decyzje dotyczące przyjmowania uchodźców, postępowanie Komisji Europejskiej przeciwko Polsce za odmowę przyjęcia uchodźców, udział ambasadora Austrii w Paradzie Równości w Warszawie, wycinka drzew w Białowieży, planowana budowa Muzeum „Sprawiedliwych spod Auschwitz”. Polska w prasie austriackiej jawi się jako państwo antyeuropejskie, antydemokratyczne, nacjonalistyczne i homofobiczne.

\section{Wnioski porównawcze $\mathrm{z}$ analizy}

Ożywienie pamięci o KL Gusen od kilkunastu lat pozostaje ważnym postulatem w rozmowach z Austrią i w polskiej polityce historycznej, a obecna partia rządząca, PiS, uczyniła z tego zagadnienia jeden ze swoich priorytetów. Dla Polaków obóz ten ma wyjątkowe znaczenie. KL Gusen i jego obóz macierzysty KL Mauthausen jako jedyne pośród wszystkich obozów koncentracyjnych i śmierci posiadały najcięższą kategorię trzecia, a przez cały czas funkcjonowania KL Gusen Polacy stanowili wśród więźniów największą grupę narodowościową. Dziś większość Austriaków nie ma wiedzy o zbrodniach w Gusen lub ją wypiera. „Za granicą ludzie są lepiej poinformowani o wydarzeniach w obozie podczas II wojny światowej niż u nas. Przy budowie sztolni [Bergkristall] leżących do $40 \mathrm{~m}$ pod ziemią zmarło ponad 10 tys. osób. To porównywalne z piramidami w Egipcie, co metr nieboszczyk" - pisze Rudolf Haunschmied, jeden z mieszkańców St. Georgen zaangażowanych w upamiętnienie KL Gusen ${ }^{107}$.

104 W. Sabitzer, Mühlviertler Hasenjagd, „Öffentliche Sicherheit”, nr 3-4/05, s. 49-51, http:// www.bmi.gv.at/magazinfiles/2005/03_04/files/9_030405.pdf (dostęp: 15 kwietnia 2018).

105 M. Rennhofer-Elbe, Im Rad der Geschichte, „Öffentliche Sicherheit”, nr 7-8/15, s. 41-42, http://www.bmi.gv.at/magazinfiles/2015/07_08/files/gedenkstaette_mauthausen.pdf (dostęp: 15 kwietnia 2018).

106 Zapowiedź obchodów przy Memoriale Gusen, w tym o koncercie, w: B. Leitner, Bevölkerung um Mauthausen soll bei Befreiungsfeier mehr Präsenz zeige, „Oberösterreichische Nachrichten”, 25 kwietnia 2017.

107 KZ-Stollen gratis zu haben, data publikacji: 1 lipca 2009 r., http://www.oe24.at/oesterreich/politik/KZ-Stollen-gratis-zu-haben/564386 (dostęp: 15 kwietnia 2018). 
„W latach 50. doszło do pewnego rodzaju konsensusu. Instytucje państwowe i organizacje byłych więźniów zgodziły się, by całe upamiętnienie scentralizować w Mauthausen. Zdajemy sobie sprawę, że ta decyzja była zła" - powiedział Ralf Lechner z austriackiego Ministerstwa Spraw Wewnętrznych ${ }^{108}$. Zdaniem Andrzeja K. Kunerta „to zapomnienie nie było tylko odgórnie sterowanym procesem, ale także oddolną »inicjatywąu lokalnych austriackich społeczności, które wypierały istnienie tych podobozów w swoim sąsiedztwie" 109 . W Polsce sytuacja też nie przedstawia się lepiej. „Bardzo mało ludzi, nawet w Polsce, wie o obozach koncentracyjnych dla Polaków, takich jak choćby obóz Mauthausen-Gusen, gdzie wymordowano kilkadziesiąt tysięcy Polaków, w tym w wielkiej części polską inteligencję" - ocenia Robert Kostro, dyrektor Muzeum Historii Polski ${ }^{110}$.

Rząd austriacki postrzega polskie dążenia do upamiętnienia własnych ofiar KL Gusen przez pryzmat nacjonalistycznych i antyunijnych tendencji w Polsce. Sprawiedliwa walka o prawdę historyczną jest przyćmiona przez wzajemny brak zaufania między Polską i Austrią - dwoma państwami, które, choć w innej skali i w inny sposób, stały się ofiarami niemieckiej nazistowskiej okupacji w latach 1939-1945.

Odwołując się do metodologii analizy dyskursu Jamesa Paula Gee, w poniższy sposób można zobrazować podstawowe wnioski z analizy dyskursu.

\section{Znaczenie}

Gusen według Polski - jedno z największych miejsc zagłady polskiej inteligencji, „drugi Katyń”, wymagające szczególnego upamiętnienia polskich ofiar; Gusen według Austrii - jeden z podobozów Mauthausen, miejsce niewolniczej pracy więźniów 27 narodów na rzecz przemysłu III Rzeszy, upamiętniony już w wystarczającym stopniu.

\section{Czynności}

Austria według Polski - niszczy, dewastuje, unika, milczy, zwodzi, nie kupuje, zabrania; Austria według Austrii - współpracuje, prowadzi dialog, upamiętnia, edukuje; Polska według Austrii - naciska, wymusza, nie rozumie, ma złą wolę, przeszkadza; Polska według Polski - chroni, przywraca, zachowuje, walczy, stara się.

\section{Tożsamości}

Polska według Austrii - państwo nacjonalistyczne, zagrażające wartościom europejskim, nieodpowiedzialne; Austria według Polski - państwo, które przedstawia się jako „pierwsza ofiara Hitlera”, a jest przynajmniej milczącym współsprawcą popełnionych na swym terytorium zbrodni nazistowskich, których nie chce odkupić.

\section{Relacje Polski i Austrii}

Poziom rządowy - nieuchronność współpracy w ramach UE i bilateralnej, wzajemny brak zaufania co do dobrych intencji drugiej strony; poziom lokalny - współpraca, osobiste znajomości, nagrody, zaufanie.

8 P. Falkowski, Sprywatyzowany obóz śmierci, „Nasz Dziennik”, 6 października 2016, s. 17.

109 A.K. Kunert, Notatka na temat kompleksu obozowego KL Mauthausen-Gusen, Rada Ochrony Pamięci Walk i Męczeństwa, data publikacji: 30 maja 2016, http://cdn.jankarski.net/files/notatkakl-mauthausen-gusen-prof--kunert.pdf (dostęp: 15 kwietnia 2018).

110 Przywróćmy pamięć o martyrologii Polaków. Rozmowa z Robertem Kostro, dyrektorem Muzeum Historii Polski, http://jakbylonaprawde.pl/przywrocmy-pamiec-o-martyrologii-polakow (dostęp: 15 kwietnia 2018). 


\section{Polityka}

Według Polski - Polska ma prawo do upamiętnienia swoich ofiar na ziemi austriackiej; Polska niezmiennie zabiega o to od wielu lat, bez względu na orientację polityczną swoich rządów; powinnością Austrii jako państwa, którego obywatele popierali politykę Adolfa Hitlera, jest wzięcie odpowiedzialności za swoją historię; reputacja Austrii jest skażona współudziałem w zbrodniach nazistowskich; Austria nic nie robi, by tę reputację poprawić; Austria jest nieuczciwa wobec Polski.

Według Austrii - Polska nie ma prawa wyróżniać swoich ofiar na tle innych narodów, które padły ofiarą Rzeszy Niemieckiej; Polska nie ma prawa nakłaniać Austrii do przepracowywania swojej przeszłości; pretensje pod adresem Austrii o zaniedbania względem Gusen są elementem nacjonalistycznej polityki polskiego rządu; Polska działa w sposób nieodpowiedzialny, nieprzemyślany i nieprzewidywalny.

\section{Połączenia}

Ważny związek: władze Polski (MSZ, MKiDN) - władze Austrii (MSW, prezydent); ważny związek: władze Polski (w tym: dyplomaci) - społeczeństwo lokalne w Austrii; ważny związek: byli więźniowie polscy - społeczeństwo lokalne w Austrii.

\section{Systemy znaków i wiedza}

Polska - język polskiej martyrologii i religijności, nastawiony na przeszłość i na upamiętnianie ofiar obozu, wzniosły, emocjonalny; Austria - język demokracji liberalnej, praktyczny, pełny poprawności politycznej, nastawiony na edukację młodzieży i na przyszłość.

Przekaz medialny w Polsce i Austrii generalnie spełnił kryterium wartości informacyjnej, czyli był atrakcyjny dla odbiorców. Większość analizowanych materiałów była możliwie aktualna, zawierała negatywne (dotyczące treści konfliktowych) i zaskakujące elementy, opisywała zjawisko z dużym natężeniem, definiowała treść jednoznacznie jako dobrą lub złą oraz wykazywała bliskość geograficzną lub kulturową opisywanego zjawiska. Wiadomości były spersonalizowane (dotyczyły jednostek), miały wpływ na życie odbiorców i odpowiadały na ich oczekiwania. Poza tym dotyczyły elit, miały konkretną treść i wiarygodne źródła pochodzenia informacji. Natomiast opisywane zdarzenia nie zawsze były przewidywalne dla odbiorów, nie zawsze stanowiły kontynuację dla informacji już wcześniej podawanych przez media i tylko część była publikowana przez poszczególne media na wyłączność.

Podsumowanie wniosków $\mathrm{z}$ analizy polskiego i austriackiego przekazu medialnego wokół 72. rocznicy wyzwolenia byłego niemieckiego obozu koncentracyjnego KL Gusen

\begin{tabular}{|l|l|}
\hline Polska narracja w mediach & Austriacka narracja w mediach \\
\hline $\begin{array}{l}\text { Gusen to symbol zbrodni niemieckich } \\
\text { podczas II wojny światowej i celowej } \\
\text { polityki zapomnienia realizowanej przez } \\
\text { Austrię od 1955 roku. }\end{array}$ & $\begin{array}{l}\text { Gusen to ogólnoludzki symbol, do czego } \\
\text { prowadzi nieprzestrzeganie praw człowieka, } \\
\text { oraz ostrzeżenie na przyszłość, jak niebez- } \\
\text { pieczne są nacjonalizm i ksenofobia. }\end{array}$ \\
\hline Rząd polski walczy o prawdę historyczną. & $\begin{array}{l}\text { Rząd polski realizuje nacjonalistyczną poli- } \\
\text { tykę oraz bezpodstawnie naciska na Austrię. }\end{array}$ \\
\hline
\end{tabular}




\begin{tabular}{|l|l|}
\hline $\begin{array}{l}\text { Gusen to przede wszystkim miejsce kaźni } \\
\text { polskiej inteligencji, miejsce planowej } \\
\text { eksterminacji narodu polskiego. }\end{array}$ & $\begin{array}{l}\text { Gusen to miejsce kaźni 27 narodów, Polska } \\
\text { nie jest tu wyjątkowa i nie powinna żądać } \\
\text { upamiętnienia swoich bohaterów na spe- } \\
\text { cjalnych zasadach. }\end{array}$ \\
\hline $\begin{array}{l}\text { Gusen powinno być traktowane jako } \\
\text { osobny obóz, odrębny od Mauthausen. }\end{array}$ & $\begin{array}{l}\text { Gusen stanowi filię Mauthausen - obozu } \\
\text { macierzystego dla wszystkich obozów } \\
\text { koncentracyjnych na terenie Austrii. }\end{array}$ \\
\hline $\begin{array}{l}\text { Gusen jako miejsce wyjątkowe w historii } \\
\text { Polski wymaga osobnego upamiętnienia. }\end{array}$ & $\begin{array}{l}\text { Miejsce pamięci w Mauthausen upamiętnia } \\
\text { również Gusen, na równi z innymi podobo- } \\
\text { zami. }\end{array}$ \\
\hline $\begin{array}{l}\text { Austria niszczy i wymazuje z pamięci } \\
\text { świadomość o Gusen. }\end{array}$ & $\begin{array}{l}\text { Austria zmaga się ze swoją przeszłością } \\
\text { i jest jej świadoma, chroni dziedzictwo } \\
\text { historyczne. }\end{array}$ \\
\hline $\begin{array}{l}\text { Cały teren po obozie powinien być } \\
\text { państwowy, należeć do Austrii. }\end{array}$ & $\begin{array}{l}\text { Teren jest w rękach prywatnych i nie ma } \\
\text { powodu, by ten stan rzeczy zmieniać. }\end{array}$ \\
\hline $\begin{array}{l}\text { Nie ma większych przeszkód prawnych, } \\
\text { by wykupić teren. }\end{array}$ & $\begin{array}{l}\text { Prawo własności to sprawa złożona, } \\
\text { wykupienie terenu od prywatnych właś- } \\
\text { cicieli nie jest łatwe, wymaga dużo czasu } \\
\text { i pieniędzy. }\end{array}$ \\
\hline
\end{tabular}

\section{Podsumowanie}

Uprawniona staje się teza, że dyskurs medialny w Polsce i w Austrii wokół 72. rocznicy wyzwolenia obozu koncentracyjnego Gusen był połączeniem dwóch dyskursów: dyskursu polityki, rozumianego jako wypowiedzi osób należących do elity władzy, oraz dyskursu politycznego, rozumianego jako dyskurs prowadzony przez elity symboliczne danego społeczeństwa (np. publicystów, intelektualistów, historyków) ${ }^{111}$.

W Polsce możemy mówić o obchodach rocznicy wyzwolenia przy Memoriale Gusen, z naciskiem na wątki polskie, natomiast w Austrii skupiono się na międzynarodowych obchodach przy Memoriale Mauthausen. Dyskurs medialny był zdominowany przez opisywanie oczekiwań strony polskiej względem władz Austrii, w Polsce przedstawianych jako uprawnione i niezależne od bieżącej sytuacji politycznej, w Austrii jako bezpodstawne i będące elementem polityki historycznej rządu RP. Można również stwierdzić, że narracja austriacka i polska o pamięci o obozie Gusen były zbudowane $\mathrm{w}$ analizowanym okresie na zasadzie przeciwstawnych perspektyw i ocen.

Można podjać próbę znalezienia przyczyn tego, że - mimo zróżnicowanego i rozbudowanego programu obchodów wyzwolenia obozu w 2017 roku - informacje na ten temat umiarkowanie przebiły się w mediach polskich, a w austriackich jeszcze słabiej. Jako pierwszą przyczynę należy wskazać równoległą organizację centralnych obchodów wyzwolenia obozu Mauthausen oraz obchodów wyzwolenia Austrii spod władzy nazi-

111 Por. M. Czyżewski, S. Kowalski, A. Piotrowski (red.), Rytualny chaos. Studium dyskursu publicznego, Wydawnictwa Akademickie i Profesjonalne, Kraków 1997, s. 21. 
stów, organizowanych na szczeblu krajowym, tzw. Dnia Pamięci przeciwko Przemocy i Rasizmowi ${ }^{112}$.

Kolejną przyczyną dość nikłej liczby relacji medialnych na temat uroczystości były inne równoległe wydarzenia $\mathrm{w}$ Polsce i na świecie. Z okazji przypadających na początek maja Święta Pracy, Dnia Flagi RP i Narodowego Święta Trzeciego Maja oraz tzw. długiego weekendu uwaga mediów w Polsce skupiła się na tematach historycznych z XVIII wieku i dotyczących wypoczynku Polaków. Jeśli chodzi o wydarzenia międzynarodowe, to poczatek maja zdominowały dwa wydarzenia. 7 maja 2017 roku odbywała się druga tura wyborów prezydenckich we Francji. Z kolei w dniach 12-13 maja 2017 roku papież Franciszek odbył podróż apostolską do Portugalii w setną rocznicę objawień fatimskich. Organizatorzy kolejnych rocznic wyzwolenia KL Gusen także będą musieli się liczyć z konkurencją innych atrakcyjnych medialnie wydarzeń.

\section{Abstract \\ Analysis of media coverage concerning the 72nd anniversary of the liberation of the former German concentration camp KL Gusen}

This article concerns the media coverage of the 72nd anniversary of the liberation of the German Nazi concentration camp KL Gusen in 2017. It was attended by the representatives of the Polish and Austrian authorities, i.e. the Secretary of State in the Ministry of Foreign Affairs Jan Dziedziczak, the Undersecretary of State in the Ministry of Culture and National Heritage Magdalena Gawin and - for the first time - by Austrian President Alexander Van der Bellen. The revival of remembrance about KL Gusen has become one of the priorities in the politics of memory pursued by the current Polish government. For Poles, the Gusen camp is of special significance because it was built with the intent of destroying the Polish intelligentsia. The Austrian government sees Polish efforts to commemorate their victims in the context of nationalist and protectionist tendencies in Poland. A just fight for historical truth is overshadowed by the mutual lack of understanding in the countries, which both suffered under German occupation between 1939 and 1945.

Keywords: Austria, Poland, Gusen, concentration camp, anniversary of liberation, media coverage, discourse analysis.

112 Pełny program polskich uroczystości 72. rocznicy wyzwolenia obozów systemu KZ Mauthausen-Gusen jest dostępny na stronie Ambasady RP w Wiedniu: http://www.wieden.msz.gov. $\mathrm{pl} / \mathrm{pl} / \mathrm{aktualnosci} / 72$ _rocznica_wyzwolenia_obozow_systemu_kz_mauthausen_gusen (dostęp: 15 kwietnia 2018). 